\title{
Varieties of verbal doubling in Romance ${ }^{*}$
}

\author{
Andrés Saab \\ CONICET / Universidad de Buenos Aires \\ alsaab75@yahoo.com.ar
}

Received: 03-09-2016

Accepted: 13-06-2017

\begin{abstract}
Recent research on verbal doubling across languages (Nunes 2004, Martins 2007, Kandybowicz 2009, Biberauer 2009, among others) shows that this phenomenon is a fruitful domain of inquiry, especially regarding the nature of copying phenomena and the way in which such phenomena interact with syntax and morphology. In line with the aforementioned works, I focus on the empirical domain of verbal doubling in Spanish and European Portuguese and argue that not all verbal doublings are the result of syntactic copying. In particular, new evidence is discussed in order to show that predicate fronting in Spanish does not result from copying the overt lower predicate (pace Vicente 2007, 2009). Other varieties of verbal duplication, such as non-local doublings in Rioplatense Spanish and Italian, and local doublings in European Portuguese, are instead the direct result of verbal copy pronunciation arising from complex factors involving the structure of remnant movement and the general conditions that regulate copy pronunciation in syntax and morphology.
\end{abstract}

Keywords: verbal doubling; Rioplatense Spanish; European Portuguese; Copy; Ellipsis; I-Assignment.

\footnotetext{
* This paper is based on a talk I gave in Utrecht in 2011, where I tried to refine some aspects of the analysis of Rioplatense verbal doubling I had defended in my Doctoral Dissertation (Saab 2008). I am grateful to Norbert Corver and Marjo van Koppen for inviting me to give that talk and the audience for comments and suggestions. Carlos Muñoz Pérez and Jairo Nunes have read a previous version of this paper and provided great feedback. I am also grateful to three anonymous reviewers for detailed criticism. Space considerations prevented me to do justice to all their comments, but I have tried at least to answer some of their main concerns. Thanks also to Ángel Gallego for his interest in my work and Cristina Real for her patience and editorial assistance. Finally, I would like to express my gratitude to Leopoldo Labastía for proofreading this paper. Usual disclaimers apply.
} 
Para Inés Kuguel, In Memoriam

\section{Table of Contents}

\section{Introduction}

2. Two types of verbal doubling in Spanish

3. Theoretical background: Iassignment

4. Rioplatense Spanish verbal doubling
5. Local and non-local doubling in Romance: the case of Portuguese 6. Summary of findings and further directions References

\section{Introduction}

Verbal doubling among languages (Vata, Koopman 1984; Nupe, Kandybowicz 2007, 2008; Afrikaans, Biberauer 2009, among others) has been taken as clear evidence in favor of the copy theory of movement (Chomsky 1993, 1995, and, especially, Nunes 1999, 2004 and the articles in Nunes \& Corver 2007).

Within the Romance domain, verbal doubling is found in Río de La Plata Spanish (Saab 2008, 2011), Italian and Roman Italian (Gullì 2003 and Jokilehto 2016, respectively), and European Portuguese (Martins 2007, 2013). As shown in (3B), European Portuguese also presents a type of local doubling not attested in Italian or Spanish:

(1) Río de la Plata Spanish

Vino Juan, vino.

came J. came

'John came!'

(2) Italian

$\begin{array}{cllll}\text { a. } \begin{array}{l}\mathbf{E} \\ \text { andato }\end{array} & \text { a } & \text { Parigi, è } & \text { andato. } \\ \text { is gone } & \text { to } & \text { Paris is } & \text { gone }\end{array}$

'He really did go to Paris.'

[Gullì 2003: 3]

b. Mangia la pizza, mangia.

eats the pizza eats

'He really is eating the pizza.'

[Gullì 2003: 31]

(3) European Portuguese

A: O João não comprou o carro, pois não? the J. not bought the car, pois neg 'John didn't buy the car, did he?'

B: Comprou, comprou.

bought, bought

'Yes, he DID.' 
(4)

\begin{tabular}{|c|c|c|c|}
\hline $\begin{array}{l}\text { A: Ele não } \\
\text { he not bc } \\
\text { 'He didn't bu }\end{array}$ & $\begin{array}{l}\text { comprou } \\
\text { bought } \\
\text { uy the car. }\end{array}$ & $\begin{array}{l}\mathrm{O} \\
\text { the }\end{array}$ & $\begin{array}{l}\text { carro. } \\
\text { car }\end{array}$ \\
\hline $\begin{array}{l}\text { B: Ele comprou } \\
\text { he bought } \\
\text { 'He did buy th }\end{array}$ & $\begin{array}{l}\text { u } \\
\text { the } \\
\text { the car.' }\end{array}$ & $\begin{array}{l}\text { carro, } \\
\text { car, }\end{array}$ & $\begin{array}{l}\text { comprou. } \\
\text { bought }\end{array}$ \\
\hline
\end{tabular}

[Martins 2007: 81]

Other type of verbal doubling, namely $v(\mathrm{P})$-topicalization (also called predicate-cleft) has also been claimed to be the result of copying the lower overt predicate (Brazilian Portuguese, Bastos 2001; Italian, Gullì 2003; Hebrew, Landau 2006; Spanish, Vicente 2007, 2009), although its status is still controversial (Cable 2004).

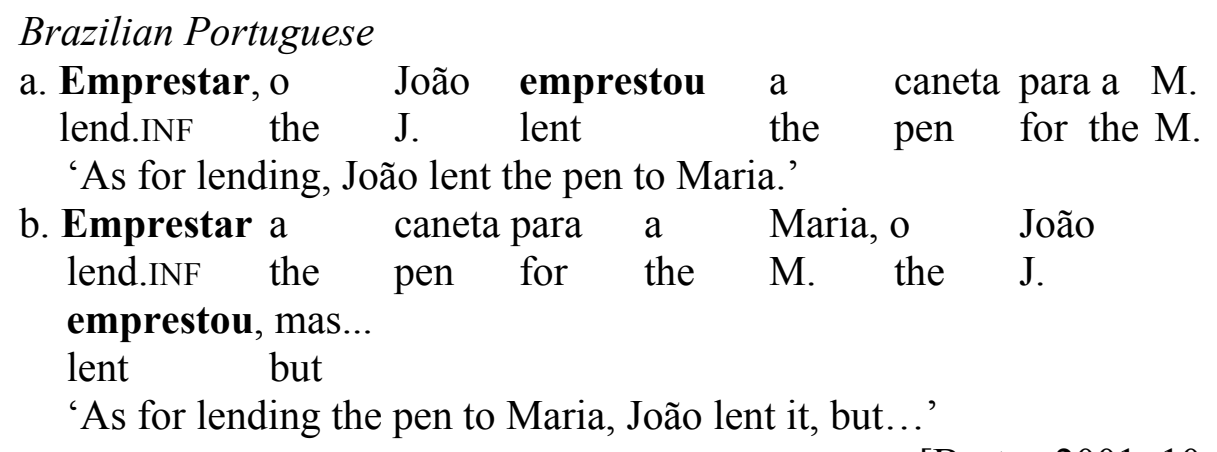

(6)

Spanish

[Bastos 2001: 10-11]
a. Comprar, compré un auto. buy.INF bought.1sG a car
'As for buying, I bought a car.'
b. Comprar el auto, lo compré este verano. buy.INF the car it bought.1SG this summer
'As for buying the car, I bought the car this summer.'

As other syntactic doubling phenomena, verbal doubling raises, at least, the following questions:

(Q1) On the basis of what empirical evidence can we tell whether or not a given doubling phenomenon is the result of copying the same syntactic object?

(Q2) Under what conditions does copy pronunciation arise as a grammatical option?

Answering (Q1) is largely an empirical matter. On the basis of Spanish data, I will show here that verbal doubling, but not $v$ P-topicalization (pace Vicente 2007, 2009), is an instance of double copy realization. To answer this question, I will contrast and evaluate the putative evidence for verbal doubling in Rioplatense Spanish and for $v$ P-topicalization typically attested in most (if not all) dialects of Spanish, both phenomena discussed in Saab (2008, 2011) and Vicente (2007, 2009), respectively. As for (Q2), I contend that there is a crucial distinction between head and phrasal copies. Whereas phrasal copies are deleted in the syntax, head 
copies are deleted at PF under the same conditions that apply for other postsyntactic phenomena, such as affix movement (Embick \& Noyer 2001). These conditions are immediate locality and adjacency. Whenever these conditions are not met, copy pronunciation arises. Other cases of local doubling (3B) follow from a general restriction on ellipsis that prevents deletion of sub-words.

Except for some brief comments in the concluding section, this paper does not address the important issue of the semantico-pragmatic import of verbal doubling across Romance varieties. Yet, this is an important source of variation in Romance and beyond. In any case, all verbal reduplication structures I am aware of seem to involve the left periphery of the clause, giving partial support to many of the analyses available in the literature. Just to take an example of the many informative values that verbal doubling can take, notice that (4B) in European Portuguese is used as an answer to a previous negative statement (Martins 2007, 2013), which makes the distribution of this type of verbal doubling extremely restricted. In contradistinction, Rioplatense verbal doubling is not natural in the same context as European Portuguese. Typically, verbal doubling in Río de La Plata Spanish can be used as commands, discourse initial contexts, answers to questions and so on, showing that its distribution is much more liberal. On the other hand, as opposed to Italian, verbal doubling in this dialect cannot be used in contrastive focus contexts (Gullì 2003), and even though it seems to be compatible with mirativity as in Roman Italian (Jokilehto 2016), it is clearly not restricted to this semantico-pragmatic value. Further research is needed in order to establish the correct correlations across Romance languages that would account for the different semantico-pragmatic import of verbal doubling.

The paper is organized in the following way. In section 2, I contrast Rioplatense verbal doubling with $v \mathrm{P}$-Topicalization and show that only the former is the result of double copy pronunciation. In section 3, I introduce and discuss the main assumptions of the theoretical framework I adopt here. In section 4, non-local verbal doubling of the Rioplatense type (1) is discussed at length under the system introduced in the previous section. As I will argue, anti-adjacency effects follow if head copies are "deleted" at PF under the same conditions that apply, for instance, in cases of local affixation. In section 5, I account for local doublings in European Portuguese (3B) and show why my account is superior to previous analysis (Martins 2007, 2013). In section 6, I summarize the main findings of this paper and discuss further directions regarding the (micro)parametric aspects that connect verbal doublings across Romance varieties to their discourse-related effects.

\section{Two types of verbal doubling in Spanish}

As mentioned in the introduction, both Rioplatense verbal doubling and $v \mathrm{P}$ topicalization have been analyzed in terms of double copy realization (see Saab 2008, 2011 and Vicente 2007, 2009, respectively), as this is understood under the umbrella of the copy theory of movement (Chomsky 1993, 1995), according to which regular displacement effects in natural language are obtained in two basic steps, namely: (i) copying a syntactic object and merging the new copy with another syntactic object in the working space of a given derivation, and (ii) deleting the lower copy (or copies) by ellipsis (as in Chomsky 1995) or by some 
mechanism of chain reduction (as in Nunes 1999, 2004). Just to grasp the idea at its most intuitive level, consider the example in (7a) and its associated basic analysis in (7b), where superscripts indicate copies:
a. John was arrested.
b. [John ${ }^{\mathrm{i}}$ [was [arrested John $\left.\left.\left.{ }^{\mathrm{i}}\right]\right]\right]$

On this theory, there are (at least) two occurrences of the lexical item John as the result of syntactic copying. To know whether two superficially identical (or non-distinct) syntactic objects count as originating from the same lexical item or not is at the heart of the copy theory of movement (see Muñoz Pérez 2017 for recent discussion). In cases like (7), in which we have the expected pattern, the issue is hard to evaluate. Yet, deviations of such a general pattern are attested in natural language as extensively discussed in Nunes' work. Instances of multiple copy realization (i.e., cases where ellipsis / chain reduction fails) are of special interest for the purposes of the ongoing discussion. Here are some well-known examples of $w$ h-doubling:

(8) Afrikaans

$\begin{array}{lllllll}\text { Met wie het jy nou weer gesê met wie het } \\ \text { with who did } & \text { you now again said with whom did } \\ \text { Sarie gedog } & \text { met wie gaan Jan trou } \\ \text { Sarie thought } & \text { with who go Jan marry } \\ \text { 'Whom did you say (again) that Sarie thought Jan is going to marry?' }\end{array}$

(9) German

Wem glaubt Hans wem Jakob gesehen hat? whom thinks Hans whom Jakob seen has

'Who does Hans think Jakob saw?

(10) Romani
Kas misline
kas o
Demiri dikhlâ?
whom think.2SG whom the
Demir saw
'Who do you think Demir saw?'

(11) Frisian

Wêr tinke jo wêr't Jan wennet? where think you where-that Jan lives

'Where do you think that Jan lives?'

(12) English Child Grammar

Who do you think really who's in the can?

[see Nunes 2004: 38 for the sources of the examples]

Taking for granted that these are true instances of multiple realizations of $w h$-copies, we see that the lower copies in each example are strictly identical to their antecedent copy. At first glance it would seem that strict identity is a logical consequence of copying a constituent. However, depending on certain assumptions 
about word and phrasal formation, this conclusion does not follow. Indeed, cases of partial wh-copying are attested in some languages. For instance, Barbiers et al (2010) have discussed partial wh-copying in different dialects of Dutch. As illustrated in (13)-(15), and unlike the examples in (8)-(12), the surface forms of each intermediate $w h$-copy is superficially non-identical to its antecedent copy.

Neuter and non-neuter wh-pronouns (Overijssel)
Wat denk je wie ik ezien heb?
what think you who I
'Who do you think I saw?'

(14) Non-neuter and (non-neuter) relative pronouns (North-Holland)

Wie denk je die ik gezien heb?

who think yo rel.PRON I seen have

'Who do you think I saw?'

(15) Neuter and (non-neuter) relative pronouns (Overijssel)

Wat denk je die ik gezien heb?

what think you rel.PRON I seen have

'Who do you think I saw?'

Barbiers et al claim that the wh-elements involved in these examples phonetically realize different layers of the DP structure, with wat realizing the lower NP layer and die the higher DP layer.

(16) DP structure:

[DP D+definite [PhiP Phi+gender [QP Q] ] ]

(17) Phonetic realization of wh-constituents:

a. $w a t=$ indefinite numeral $(\mathrm{QP})$

b. wie $=$ wat $+\varphi$-features (PhiP)

c. $d i e=w i e+$ definiteness $(\mathrm{DP})$

Partial identity effects in these paradigms can be now derived as cases of regular $w h$-copying. Take the sentence in (15) as illustration. The surface result is obtained if the system makes a copy out of the lower DP layer of the intermediate copy and merges the result in the matrix CP. As a byproduct of this partial copying, and assuming the analysis in (17), the right result is obtained (see Barbiers et al 2010 and Muñoz Pérez 2017 for detailed discussion):

$$
\begin{array}{lll}
{\left[\mathrm{QP}_{\mathrm{Q}} \mathrm{Q}\right]^{\mathrm{i}}} & \cdots & {\left[\mathrm{DP} \mathrm{D}+\text { definite }\left[\text { PhiP Phi+gender }[\mathrm{QP} Q]^{\mathrm{i}}\right]\right]} \\
\text { wat } & & \text { die }
\end{array}
$$

The net prediction of this approach is that the higher wh-copy cannot be over-specified with respect the intermediate one. This is borne out: 
*Wie denk je wat ik gezien heb?

who think you what I seen have

'Who do you think I saw?'

$\begin{array}{llllll}* \text { Die } & \text { denk } & \text { je } & \text { wie } & \text { ik } & \text { gezien heb? } \\ \text { rel.PRON } & \text { think } & \text { you } & \text { who } & \text { I } & \text { seen have }\end{array}$

'Who do you think I saw?'

$\begin{array}{lllll}\text { *Die denk je } & \text { wat } & \text { ik } & \text { gezien heb? } \\ \text { rel.PRON think you } & \text { what } & \text { I } & \text { seen have } \\ \text { 'Who do you think I saw?' } & & & & \end{array}$

Therefore, we have robust evidence from the wh-domain for full and partial copying. With this background in mind, let us come back to the Spanish facts introduced above and see whether a similar strategy could account for the paradigms at hand.

\subsection{Evidence for double copy pronunciation in Rio de La Plata Spanish}

Verbal doubling in Rioplatense Spanish has a similarity with the wh-doubling examples in (8)-(12), namely, the lower visible copy must be strictly identical to the higher one. Superficially, the construction at hand responds to the pattern we see in (22c), where the two verbs involved in the sentence have to be strictly identical and anti-adjacent, a property to be discussed at length in section 4 . The comma preceding the last verb indicates a brief prosodic break triggering deaccenting of such a verb. In turn, sentential focus falls on the underlined constituent. ${ }^{1}$

$$
\begin{aligned}
& \text { a. Vino Juan, vino. } \\
& \text { came J. came } \\
& \text { 'John came!' } \\
& \text { b. *Juan vino vino. } \\
& \text { c. } \mathrm{V}_{1} \mathrm{XP}, \mathrm{V}_{2} \text {. }
\end{aligned}
$$

Two additional properties discussed in Saab $(2008,2011)$ provide further evidence in favor of the idea that the phenomenon underlying verbal doubling in (22) is indeed the result of copy pronunciation. Suppose $V_{1}$ is a transitive verb whose direct object is definite (e.g., compré el auto 'I bought the car', limpié la casa 'I cleaned the house', etc.). Under this circumstance if $\mathrm{V}_{2}$ was an instance of a different verb occurring in a different sentence, we would predict pronominalization by an accusative clitic within the putative second sentence.

${ }^{1}$ According to Martins (2013), Italian examples such as (2b), repeated below, show a very similar prosodic pattern:

(i) Mangia la pizza, mangia.

eats the pizza eats

'He really is eating the pizza.'

[Gullì 2003: 31]

The fact that the second verb is unstressed is taken by Martins as evidence against a monoclausal analysis, given that such a verb would not be integrated into the same prosodic unit (Martins 2013: 98). As I will show in this section, this conclusion does not follow. 
However, this is strongly ungrammatical: $V_{2}$ does not tolerate accusative pronominalization:
a. Compré el auto, (*1o) bought.1SG the car CL.ACC.3.MASC.SG 'I bought the car!'
b. Limpié la cleaned.1SG the
'I cleaned the house!'
casa, (*la) limpié.
house CL.ACC.3.FEM.SG cleaned.1SG

Spanish, as is well-known, does not allow definite null objects (Campos 1986, 1999 and the references therein) and does not have V-stranding VP-ellipsis (Goldberg 2005):
A: ¿Compraste las manzanas? bought.2SG the apples
B: *Sí, compré. yes bought.1sg 'Yes, I did.'
A: ¿Limpiaste
la casa? cleaned.2sG the house 'Did you clean your house?'

B: *Sí, limpié.

yes, cleaned.1SG

'Yes, I did.'

Then, given that Rioplatense Spanish lacks both definite null objects and VP-ellipsis, the bi-clausal hypothesis cannot be on the right track. Put differently, $\mathrm{V}_{1}$ and $\mathrm{V}_{2}$ must form a (head) chain in a single sentence.

A second reason leading to the same conclusion is connected to clitic realization. Specifically, if a clitic is attached to $\mathrm{V}_{1}$, an identical clitic must also be attached to $\mathrm{V}_{2}$ :

$$
\begin{array}{llll}
\text { a. Lo } & \text { atamos } & \text { con } & \text { alambre, } \\
\text { CL.ACC.3.MASC.SG } & \text { tie.1PL } & \text { with wire } \\
\text { (lo) } & \text { atamos. } & \\
\text { CL.ACC.3.MASC.SG } & \text { tie.1PL }
\end{array}
$$

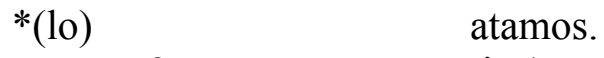

The same with clitic clusters: 


$\begin{array}{lll}\text { Me lo } & \text { dio } & \text { Pedro, me } \\ \text { CL.DAT.1SG CL.ACC.3.MASC.SG } & \text { gave } & \text { P. CL.DAT.1SG } \\ \text { lo } & & \\ \text { CL.ACC.3.MASC.SG gave } & & \\ \text { 'Pedro gave it to me!' }\end{array}$

Yet, a full direct object (or any other complements) occurring with $\mathrm{V}_{1}$ cannot be replicated in the $\mathrm{V}_{2}$ domain:
a. *Compré el auto, compré el auto. bought.1SG the car bought.1SG the car 'I bought the car!'
b. *Limpié cleaned.1SG the 'I cleaned the house!' la casa, limpié la casa.

In sum, these and other properties to be discussed below point in favor of an analysis in terms of head copy realization. Following Martins' (2007) analysis for European Portuguese, let us assume that the verb moves cyclically from its base position to some high position in the C-domain. Remnant movement of the phrase excluding the high copy of the verb (by assumption, $\Sigma$ P) would partially account for the surface ordering. As a first approximation to the proper analysis for $(29 a)$, consider the tree in $(29 b)$ :
a. Compró el auto, compró.
bought the car, bought.

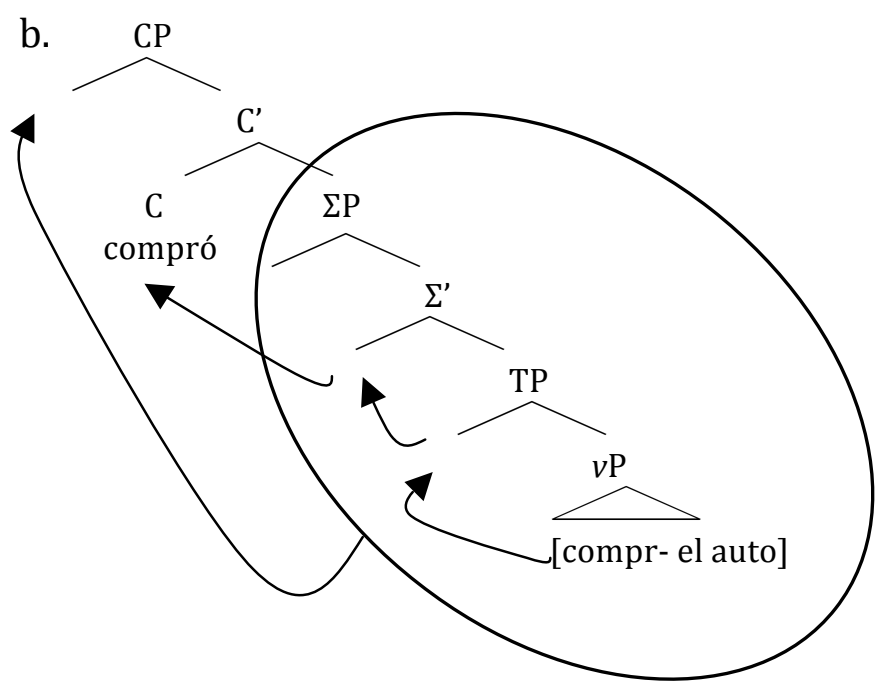

On this analysis, two properties of verbal doubling follow automatically, namely, absence of pronominalization and the ban on replicating full complements in the $\mathrm{V}_{2}$ domain. The first fact is explained by absence of any clitic pronoun within $\Sigma$ P as shown in (29b). The second fact, in turn, reduces to the head nature of verbal doubling in this dialect (see section 4 for details). As for the requirement of clitic repetition, we can assume that the verb pied-pipes the clitics 
inside $\Sigma \mathrm{P}$ on its way to the $\mathrm{C}$ head. Put differently, $\mathrm{V}_{2}$ can be a complex head, but not a phrase. Finally, the prosodic pattern also receives a natural account. Recall that sentential focus falls on the most embedded constituent preceding the last verb. If the entire sentence moves to Spec,CP, we expect Spanish stress rules to apply in the normal way, namely, assigning main sentential stress to the most embedded constituent within $\Sigma$ P (Zubizarreta 1998) and deaccenting any constituent out of the focus set of the sentence (i.e., V2). We will present further evidence for this particular analysis in section 4.

\subsection{Evidence against double copy pronunciation in Spanish vP-Topicalization}

Now, let's see whether or not there are arguments in favor of an analysis in terms of double copy realization for $v$ P-topicalization. Recall the data in $(6 \mathrm{~b}):^{2}$

$$
\begin{aligned}
& \text { Comprar el auto, lo compré este verano. } \\
& \text { buy.INF the car it bought.1SG this summer } \\
& \text { 'As for buying the car, I bought the car this summer.' }
\end{aligned}
$$

In (31b), Vicente's (2007) analysis is schematized. Notice that this approach is similar to the analysis for partial $w h$-doubling briefly discussed above, the main difference being in the category affected by movement ( $v \mathrm{P}$, in this case):

$$
\begin{array}{lllllll}
\text { a. } & \text { [Leer } & \text { el } & \text { libro] Juan } & \text { ha leído el } & \text { libro. } \\
\text { read.INF } & \text { the } & \text { book } & \text { J. } & \text { has } & \text { read the } & \text { book }
\end{array}
$$

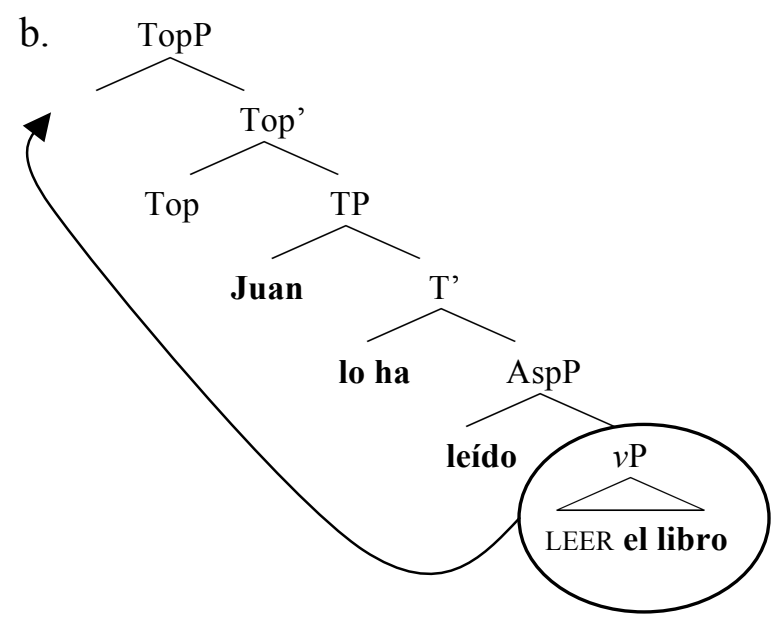

${ }^{2}$ I leave aside cases of $v$-topicalization (see (i)), which are also analyzed by Vicente $(2007,2009)$ as the result of verbal copy duplication. As far as I can tell, an analysis in terms of long-head movement along the lines of Vicente's proposal or my own proposal in section 5 for Vata and European Portuguese could account for some of the particular properties of this construction.
(i) Comprar, compré un auto. (cf. 6)
buy.INF bought.1SG a car
'As for buying, I bought a car.' 
Putative evidence for movement comes from islands effects (32)-(34) and the (in)compatibility with genus-species readings (35) (Cable 2004, Landau 2006 and Vicente 2007, 2009):

\section{Island effects:}

(32) Bridge verb

Comprar el libro, Juan dijo que lo compró.

buy.INF the book J. said that it bought

'As for buying the book, Juan said that he bought it.'

Relative island
*Comprar el libro, conozco
buy.INF the book know.1SG to the la persona que
$\begin{aligned} & \text { lo compró. } \\ & \text { it bought }\end{aligned}$

(34) Adjunct island

$\begin{array}{lllll}\text { *Comprar el libro, Juan } & \text { se enojó porque } \\ \text { buy.INF } & \begin{array}{l}\text { the book } \\ \text { compró }\end{array} & \text { SE } & \text { upset because } \\ \text { Pedro lo } & \begin{array}{l}\text { compró } \\ \text { bought }\end{array} & & & \\ \text { P. it } & & & & \end{array}$

\section{Genus-species reading:}

$\begin{array}{cllll}\% \text { Comer } & \text { pescado, } & \text { solo } & \text { como } & \text { salmón. } \\ \text { eat.INF } & \text { fish } & \text { only } & \text { eat. } 1 \mathrm{SG} & \text { salmon }\end{array}$

'As for eating fish, I only eat salmon.'

Island effects are not conclusive, though; what they show is that there is A'-extraction from the position in which the topic is interpreted. Following Iatridou's (1995) analysis of Clitic Left Dislocation, Cable (2004) argues that a $v \mathrm{P}$-topic can be generated in the left periphery of the source sentence:

$$
\begin{aligned}
& v P \text { base-generation } \\
& {[\text { СР } \ldots[\text { СР } \ldots[\text { СР } \boldsymbol{v P} \text {-topic }[\text { ТР } \ldots}
\end{aligned}
$$

Now, it follows that $\mathrm{A}^{\prime}$-extraction from the most embedded $\mathrm{CP}$ is illegitimate whenever it crosses certain types of islands. Put differently, sensitivity to islands cannot be taken as evidence in favor of copy pronunciation, but just as topic movement of a base-generated constituent. ${ }^{3}$

\footnotetext{
${ }^{3}$ Island sensitivity is also compatible with an analysis along the lines proposed by Ott (2015) for deriving split topics (see footnote 4). On this account, a given dislocated $v \mathrm{P}$ would be part of a "big $v \mathrm{P}$ " containing the lower predicate. The doubling $v \mathrm{P}$ then would move to the left periphery. At any rate, again, island sensitivity does not provide conclusive evidence for a partial copy analysis of $v \mathrm{P}$-Topicalization; it only tells us that the dislocated $v \mathrm{P}$ can be subject to $\mathrm{A}^{\prime}$ extraction from its original clause.
} 
As for the ban of genus-species reading, it would immediately follow if the fronted predicate was a syntactic copy of the lower predicate, under the crucial assumption that no semantic dependency can be established between subconstituents of a given non-trivial chain. In this case, moreover, there is an absolute lack of syntactic identity between the sub-constituents at hand (the direct objects pescado and salmón). Yet, it should be noted that the genus-species reading is not ungrammatical for some speakers. On the face of this, Vicente proposes a base-generation analysis for those speakers that accept the genusspecies reading and a movement analysis for those speakers that do not. ${ }^{4}$ This is an undesirable conclusion in view of the fact that the genus-species reading is the only putative argument for diagnosing movement. A semantic alternative for the genus-species effect is developed in Cable (2004). I refer the reader to his work for details. ${ }^{5}$ In the remaining part of this section, I present three arguments against a movement analysis for $v$ P-topicalization.

Argument \#1: pronominalization effects. The analysis in terms of movement for $v$ P-topicalization predicts exactly the same absence of clitic replacement that we observe in verbal doubling in Rioplatense Spanish. This prediction, however, is not borne out. Indeed, what we find is the same pattern of pronominalization that must apply across sentences in most Spanish dialects. In this respect, compare the following sentences:

$\begin{array}{llll}\text { Comprar el auto, } & *(10) & \text { compré } & \text { ayer. } \\ \text { buy.INF the car } & \text { CL.ACC.3.MASC.SG } & \text { bought.1SG } & \text { yesterday }\end{array}$

'As for buying the car, I bought the car yesterday.'

\begin{tabular}{|c|c|c|c|c|}
\hline $\begin{array}{l}\text { Compré } \\
\text { bought.1SG }\end{array}$ & $\begin{array}{ll}\text { el auto. } & \text { car } \\
\text { the } & \text { cal }\end{array}$ & $\begin{array}{l}*(\mathrm{Lo}) \\
\text { (it) }\end{array}$ & $\begin{array}{l}\text { compré } \\
\text { bought.1SG }\end{array}$ & $\begin{array}{l}\text { el } \\
\text { the }\end{array}$ \\
\hline
\end{tabular}

Vicente admits this problem and claims: I must leave the trigger of clitic doubling as an unsolved problem (Vicente 2009, footnote 23, 183). But notice that this is not clitic doubling but just the result of accusative clitic replacement, an obligatory operation in most Spanish dialects whenever the antecedent DP in a given previous clause is definite. Consider again the example in (24), repeated as (39):

${ }^{4}$ As noticed by an anonymous reviewer, genus-species readings are amenable to a movement analysis at least in split topic constructions of the following type (see Ott \& Nicolae 2014):

(i) Fruta, Pedro solo come manzanas.

fruit P. only eats apples

'As for fruits, Pedro only ates apples.'

It is not obvious, however, how a movement analysis where the topic moves from a predicate position can be extended to our $v \mathrm{P}$-Topicalization cases.

${ }^{5}$ Notice that the genus-species reading is even odd (for some speakers) in hanging topic contexts, a construction for which a movement analysis is not tenable:

$\begin{array}{clllll}\text { (i) } \% \text { En cuanto a } & \text { comer } & \text { pescado, } & \text { solo } & \text { como } & \text { salmón. } \\ \text { as-for } & \text { eating } & \text { fish } & \text { only } & \text { eat.1SG } & \text { salmon }\end{array}$ 

A: ¿Compraste las manzanas? bought.2SG
the apples
'Did you buy the apples?'
B: Sí, *(las) compré.
yes CL.ACC.3.FEM.PL bought.1SG
'Yes, I did.'

In contradistinction, indefinite object drop is allowed in most Spanish varieties (Campos 1986):
A: ¿Compraste manzanas? bought.2SG apples
'Did you buy the apples?'

B: Sí, compré.

yes bought.1SG

'Yes, I did.'

Therefore, it is predicted that the same pattern of indefinite object omission should be found in $v \mathrm{P}$-topicalization environments. This is correct.

$\begin{array}{llll}\text { Comprar } & \text { manzanas, } & \text { compré } & \text { ayer. } \\ \text { buy.INF } & \text { apples } & \text { bought.1SG } & \text { yesterday }\end{array}$

'As for buying apples, I bought apples yesterday.'

One property of indefinite object drop is that it allows for adjective or quantifier modification:
A: Preferís cerveza holandesa o alemana? prefer.2SG beer Dutch or German
'Do you prefer Dutch or German beer?'
B: Prefiero holandesa.
prefer.1SG Dutch
'I prefer Dutch beer.'
A: Comés pescado?
eat.2SG fish
'Do you eat fish?'
B: Como poco.
eat.1SG little
'I eat little.'

As expected, we find exactly the same pattern in $v$ P-topicalization environments:
a. [Comer
pescado],
como
[poco $\left.\emptyset_{[-\mathrm{def}]}\right]$.
[Tomar
fish
eat.1SG
little
drink.INF
cerveza],
solo tomo
only drink.1sG
[ $\boldsymbol{\emptyset}_{\text {[-def] }}$ holandesa].
Dutch 
This lack of syntactic identity between the $v \mathrm{P}$-topic and the $v \mathrm{P}$ in the lower part of the clause cannot be derived under a partial copy analysis. In order to maintain the partial copy analysis, we should give up the assumption mentioned above that there cannot be semantic dependencies among sub-constituents of chain links. Recall that such an assumption was crucial for ruling out the genusspecies readings in examples like (35).

Argument \#2: strong pronouns, epithets and full DPs. Consider now the following paradigm:

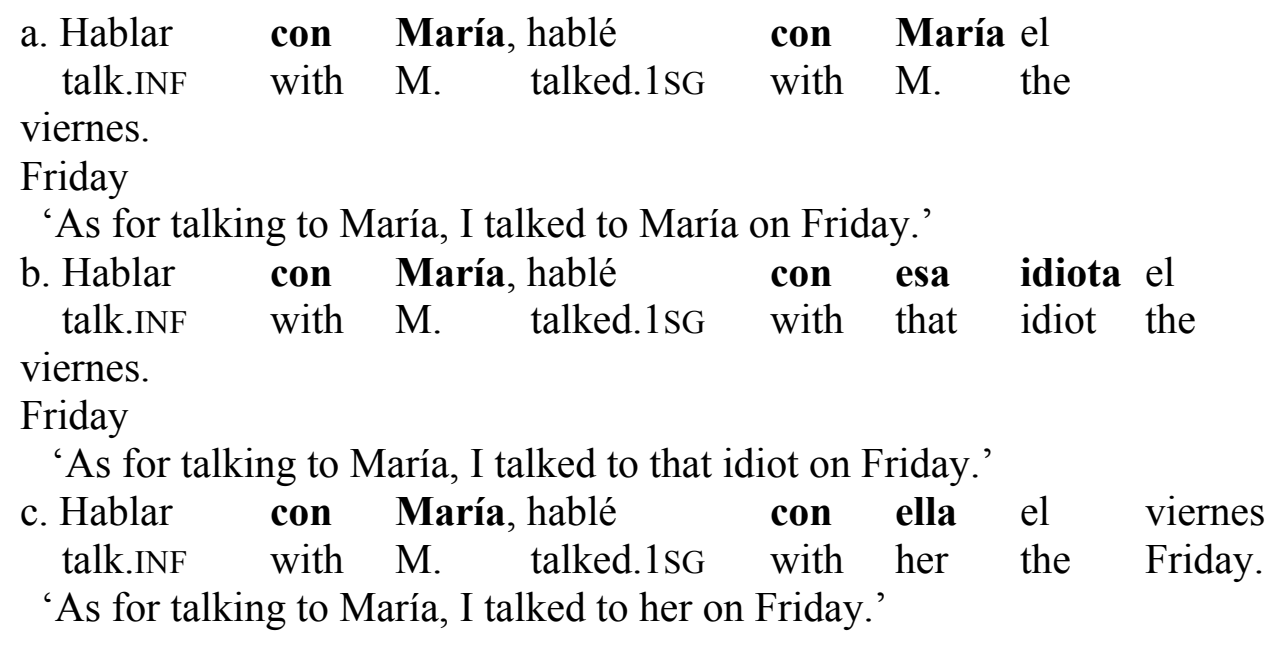

Examples (45b-c) reinforce the idea that there is no (special) clitic doubling in $v \mathrm{P}$-topicalization contexts, but pronominal replacement by a clitic (37), an epithet (45b) or a strong pronoun (45c). The sentence in (45a) presents a different problem for the analysis in terms of movement. Concretely, why is the lower occurrence of con Maria not obligatorily deleted when the $v \mathrm{P}$ is fronted?

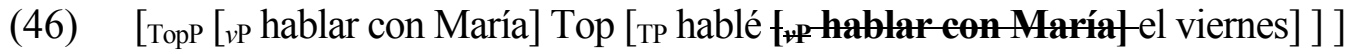

Movement of the PP out of the lower $v \mathrm{P}$ is not a solution, given that this would give us a structure where the fronted $v \mathrm{P}$ would contain a trace of the PP. In effect, moving the $\mathrm{PP}$ out of the $v \mathrm{P}$ and then extracting the $v \mathrm{P}$ as a remnant would result in the configuration in (47), not the desired result:

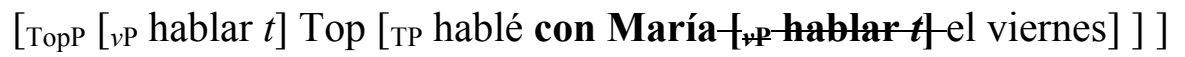

Argument \#3: Low applicatives. Finally, consider the following sentence:

$\begin{array}{lllll}\text { Construir una casa, le } & \text { construí } & \text { una casa } \\ \text { build.INF } & \text { a house } & \text { CL.DAT.3SG built.1SG } & \text { a } & \text { house } \\ \text { a mi hija. } & & & \\ \text { to my daughter } & & & \\ \text { 'As for building a house, I built a house to my daughter.' }\end{array}$


In this sentence, the lower $v \mathrm{P}$ has a low applicative phrase that is not present in the fronted $\nu \mathrm{P}$. Assuming the structure for low applicatives in (49a) (Pylkkänen 2002), the analysis in terms of movement predicts that if a low applicative is added to the $v \mathrm{P}$ structure, then the copied $v \mathrm{P}$ should include the ApplP (50).

$$
\begin{aligned}
& \text { a. } \quad\left[\mathrm { TP } \ldots \left[{ }_{v \mathrm{P}} \ldots[\mathrm{VP} \ldots[\text { ApplP } \ldots\right.\right. \\
& \text { b. } \quad\left[v \mathrm { P } \ldots \left[\begin{array}{l}
\mathrm{VP} \\
\ldots
\end{array}\right.\right.
\end{aligned}
$$

As (48) shows, this prediction is not borne out. In order for (48) to be derived as movement, we must assume that partial copy not only can affect constituents but also non-constituents.

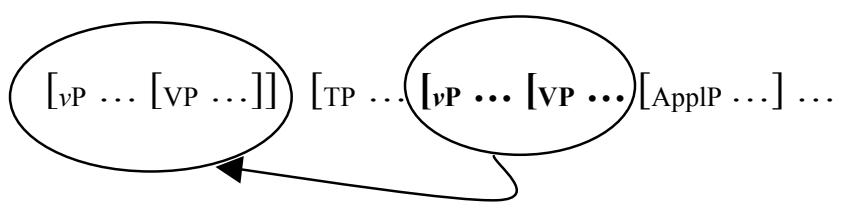

For the adduced reasons, I conclude that $v \mathrm{P}$-fronting cannot be the result of partial predicate fronting. I therefore subscribe an analysis along the lines of Cable's (2004) proposal, according to which the fronted predicate is base-generated in a topic position within the source clause and does not form a movement chain with the lower $v \mathrm{P}$ (subscripts indicate different syntactic objects):

vP-topicalization: base-generation

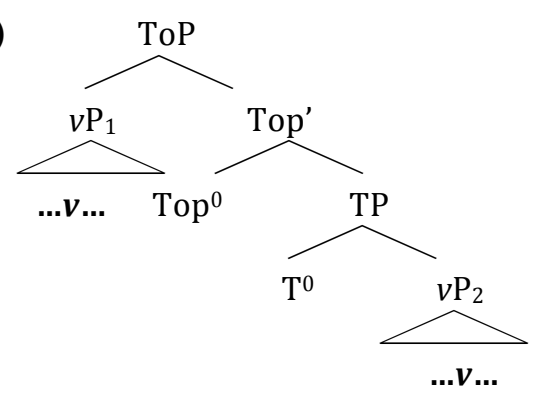

In summary, in this section, I have provided an answer to the first question raised in the introduction:

(Q1) On the basis of what empirical evidence can we tell whether or not a given doubling phenomenon is the result of copying the same syntactic object?

The evidence has to be constructed on the basis of particular properties of the languages under consideration. As for Spanish in general, different syntactic and semantic diagnostics lead to the conclusion that $v \mathrm{P}$-fronting cannot be derived as a variety of syntactic copying (specifically, partial copying). Yet, there are attested cases of verbal copying in the particular case of Rioplatense Spanish, where there is robust evidence pointing out to the conclusion that the two verbs 
involved in the construction are phonetic realizations of particular links in a head chain. This, in turn, leads us to the second main question:

(Q2) Under what conditions does copy pronunciation arise as a grammatical option?

I give an explicit general answer in the next section, before turning to the particular domain of verbal copy pronunciation in Río de La Plata Spanish.

\section{Theoretical background: I-Assignment}

In Saab (2008), I propose that grammatical silences are the result of a morphosyntactic operation, I-Assignment. This operation is responsible for regulating the "how and when" regarding the (non)-pronunciation of the objects that syntax produces. I-Assignment can only affect phrases or heads under formal identity. In (52), I schematize these two options for any merged objects $\mathrm{Y}$ and $\mathrm{X}$, with $\mathrm{X}$ as a label.
a. $\left\{\mathrm{X}^{[\mathrm{I}]}\{\mathrm{X}, \mathrm{Y}\}\right\}$
b. $\left\{\mathrm{X}\left\{\mathrm{X}^{[\mathrm{I}]}, \mathrm{Y}\right\}\right\}$

What differentiates phrasal I-Assignment and head I-Assignment is the component of the grammar in which it takes place. Whereas phrases are $I$-Assigned in the syntax under syntactic conditions, such as c-command or E-selection (Merchant 2001), heads are $I$-assigned at PF under morphological conditions, such as immediate locality or adjacency. Such conditions for I-Assignment define what I call I-Assignment cycles. Any syntactic object affected by I-Assignment in a given cycle would result in a silent object at PF. Three empirical domains are explored in detail in Saab (2008), namely copy deletion, null subjects and different varieties of elliptical phenomena. Here, I only focus on how copy deletion and copy realization is explained under the I-Assignment system. Copy deletion, as other elliptical phenomena, is implemented entirely in the syntax or at PF, depending on the phrasal status of the syntactic object at hand:

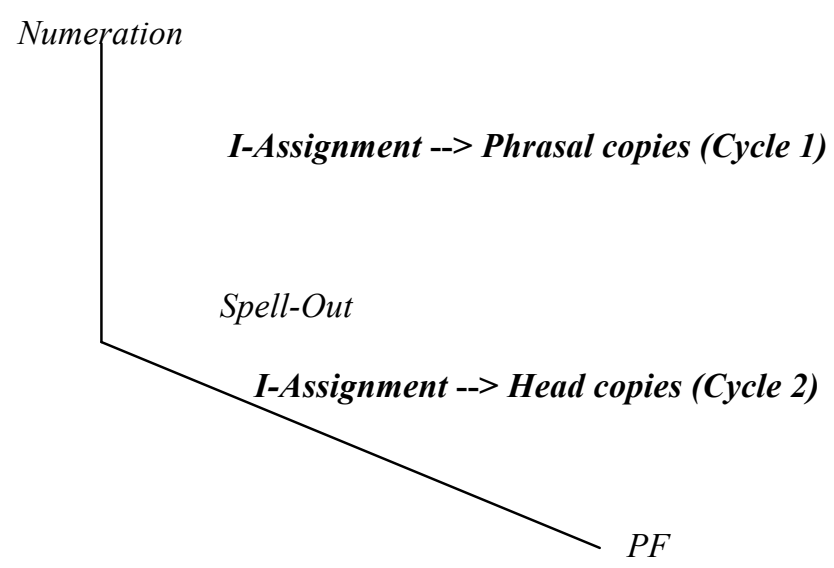


Let's start with phrasal copies. I assume that the conditions in (54) trigger one I-Assignment cycle in the syntax:

Phrasal I-Assignment in the syntax (simplified version):

A copy $\mathrm{C}$ is $I$-assigned if and only if there is an antecedent copy $\mathrm{AC}$ for $\mathrm{C}$, such that:

(i) $\mathrm{AC}$ and $\mathrm{C}$ are identical, and

(ii) AC c-commands $\mathrm{C}$.

I will not discuss how identity and chain formation between $\mathrm{AC}$ and $\mathrm{C}$ must be defined as both points are orthogonal to our main discussion (see Muñoz Pérez 2017 for detailed discussion). I just suppose that chain links satisfy some sort of identity, which in the ideal case is the same sort of identity condition that applies to other elliptical dependencies (ellipsis, null arguments and so on). Put differently, by assumption, the computational system has a unique identity condition applying all the way. The c-command condition deserves more elaboration, because it is at the heart of the phrasal and head division as far as the I-Assignment system is concerned. I adopt Chomsky's (2000) definition of c-command:

C-command:

$\alpha \mathrm{c}$-commands $\beta$ if $\alpha$ is a sister of $\mathrm{K}$ that contains $\beta$.

[Chomsky 2000: 116]

For any two-link chain, where the two conditions in (54) are met, $I$ Assignment applies and adds an $[\mathrm{I}($ dentity)] feature to the label of the relevant phrasal link:
a. [John was [punished John $\left.\left.{ }^{[I]}\right]\right]$
b. $\left\{\mathrm{D}^{[\mathrm{I}]}\{\mathrm{D}, \mathrm{John}\}\right\}$

The PF effect of $I$-Assignment must be understood in the framework of a realizational approach to grammar, in which phonological information is supplied late for abstract terminal nodes in the PF branch of the grammar (Distributed Morphology, Halle \& Marantz 1993 and much subsequent work). Phonological information is added through a PF operation called Vocabulary Insertion, which inserts Vocabulary Items (VI) pertaining to a list of PF primitives. In (57), I illustrate the general form of a VI with the regular past in English (see Embick 2015 for detailed discussion on the VI mechanics):

$$
\mathrm{T}[\text { past }] \leftrightarrow-e d
$$

Thus, a given VI contains instructions for its insertion in a given syntactic terminal node. In the case at hand, the exponent - $e d$ is inserted as the default form of the past tense node by rules like the following one:

$$
\mathrm{T}[\text { past }] \rightarrow \mathrm{T}[\text { past, }-e d]
$$


Saab proposes that the direct PF effect of $I$-Assignment is blocking rules like (58). VI blocking is defined as follows (modified from Saab 2008):

(59) VI-Blocking (VIB):

Vocabulary Insertion does not apply in the domain of $X^{0}, X^{0}$ a Morphosyntactic Word, if $X^{0}$, or some projection of $X^{0}$, is specified with a [I] feature.

Associated definitions:

(i) The domain of $X^{0}, X^{0}$ a MWd, is the set of terminal nodes reflexively contained in $X^{0}$.

(ii) Morphosyntactic word

At the input to Morphology, a node $X^{0}$ is (by definition) a morphosyntactic word (MWd) iff $\mathrm{X}^{0}$ is the highest segment of an $\mathrm{X}^{0}$ not contained in another $\mathrm{X}^{0}$.

(iii) Subword

A node $\mathrm{X}^{0}$ is a subword (SWd) if $\mathrm{X}^{0}$ is a terminal node and not an $\mathrm{MWd}$.

[(ii) and (iii) from Embick \& Noyer 2001: 574]

This definition of VIB implicitly leads to what I call the Sub-Word Deletion Corollary:

(60) Sub-Word Deletion Corollary:

The [I] feature is inert below the MWd level.

So, suppose that a SWd bears a [I] feature acquired at some point in the course of a derivation:

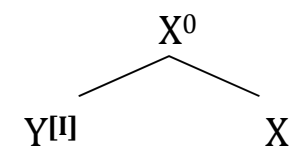

By the VIB definition, the $I$-assigned SWd in (61), Y, is subjected to VI as if it were not $I$-marked. The inertness of the [I] feature expressed in the $S W d$ Deletion Corollary can be represented as in (62):

$$
\mathrm{Y}[+\alpha, I] \rightarrow \mathrm{Y}[+\alpha, / \mathrm{x} /, I]
$$

Thus, the I-Assignment provides an explicit answer to at least certain types of phonetic realization of copies. Let us see the effects of the SWd Deletion Corollary in the aforementioned cases of wh-copying and compare the analysis with Nunes' (2004) original proposal. Here are some of the relevant examples: 
(63) German

Wem glaub Hans wem Jakob gesehen hat? whom thinks Hans whom Jakob seen has 'Who does Hans think Jakob saw?

(64) Romani

$\begin{array}{llll}\text { Kas misline } & \text { kas o } & \text { Demiri dikhlâ? } \\ \text { Whom you-think } & \text { whom } & \text { Demir saw }\end{array}$

'Who do you think Demir saw?'

[Nunes 2004: 38 and the references therein]

In Nunes' approach, the operation copy creates contradictory linearization statements in connection with Kayne's (1994) Linear Correspondence Axiom, LCA. ${ }^{6}$ Given a simple two-link chain like (65), we can see the conflict between the LCA and the effects of copying:

[John ${ }^{\mathrm{i}}$ was [punished $\left.\left.\mathrm{John}^{\mathrm{i}}\right]\right]$

Taking for granted that the links of a given chain count as the same element, the verb punish asymmetrically c-commands the lower copy of John, but crucially it is c-commanded by the higher copy of the same constituent. By the LCA, then John precedes punish and punish precedes John violating asymmetry and irreflexivity (Nunes 2004: 24). The system avoids the problem through the following operation:

(66) Chain Reduction:

Delete the minimal number of constituents of a nontrivial chain $\mathrm{CH}$ that suffice for $\mathrm{CH}$ to be mapped into a liner order in accordance with LCA.

[Nunes 2004: 27]

Thus, Chain Reduction applies in (65) and produces a convergent output:

[John ${ }^{\mathrm{i}}$ was [punished John $\left.\left.{ }^{\mathrm{i}}\right]\right]$

If (63) and (64) are generated by cyclically copying the wh-constituent that ends up in the matrix $\mathrm{CP}$, as Nunes indeed assumes, the question is why the matrix and intermediate copies do no introduce any linearization conflict. Nunes' account proceeds in two steps:

...successive-cyclic $w h$-movement in these languages may proceed by adjunction to an intermediate $\mathrm{C}^{0}[\ldots]$ and Morphology in these languages may convert the adjunction structure $\left[{ }^{0} \mathrm{WH}\left[{ }^{0} \mathrm{C}^{0}\right]\right][\ldots]$ into a single terminal element.

[Nunes 2004: 40]

\footnotetext{
${ }^{6}$ Linear Correspondence Axiom:

Let $\mathrm{X}, \mathrm{Y}$ be nonterminals and $\mathrm{x}, \mathrm{y}$ terminals such that $\mathrm{X}$ dominates $\mathrm{x}$ and $\mathrm{Y}$ dominates $\mathrm{y}$. Then if $\mathrm{X}$ asymmetrically c-commands $\mathrm{Y}$, $\mathrm{x}$ precedes $\mathrm{y}$.

[from Kayne 1994: 34]
} 
Under the first assumption, the intermediate copy in the embedded CP adjoins to the intermediate $\mathrm{C}$ head, as illustrated in (68):

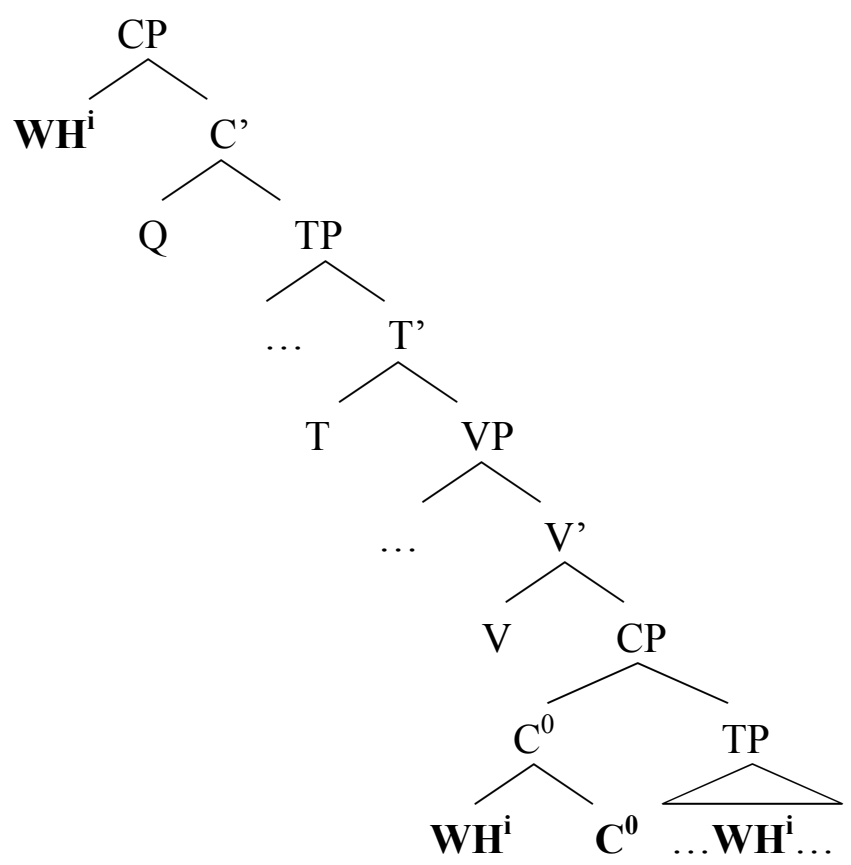

At $\mathrm{PF}$, the intermediate $w h$-copy fuses with the $\mathrm{C}$ head forming a unique terminal node:

(69) Morphological Reanalysis:

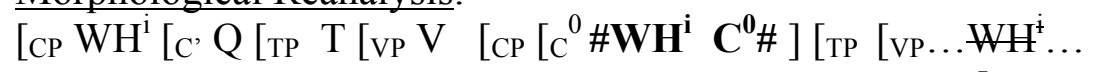

[Nunes 2004: 41]

The net result of this fusion process is making the intermediate copy distinct in such a way that the system does not recognize it as a link chain; consequently, Chain Reduction does not apply. As evidence in favor of his fusion analysis, Nunes adduces the impossibility of phonetic realization of complex wh-copies:

(70) German

*Wessen Buch glaubstdu wessen Buch Hans liest?

whose book think you whose book Hans reads

'Whose book do you think Hans is reading?'

(71) Romani

*Save chave mislinea save chave o Demiri dikhlâ?

which boy you-think which boy Demir saw

'Who do you think Demir saw?'

[McDaniel 1986 apud Nunes 2004: 18-9]

Compare now the I-Assignment system with Nunes' approach. The first thing to be noticed is that the second assumption in Nunes is an unnecessary step in my approach, as the intermediate copies in (63) and (64) are incorporated into a head, a MWd, which is not I-assigned. By the Sub-Word Deletion Corollary, then 
the intermediate copy must be phonetically realized regardless of being $I$ assigned. Given that our analysis makes use of fewer assumptions (one assumption less), it seems to be theoretically superior to Nunes'. Notice, moreover, that the same prediction arises if $w h$-movement proceeds as standardly assumed for cyclic wh-movement (72) and the intermediate wh-copy is incorporated onto $\mathrm{C}$ by some morphological process (Lowering or Local Dislocation; see Embick \& Noyer 2001):

Syntax: Regular wh-movement + I-Assignment under c-command

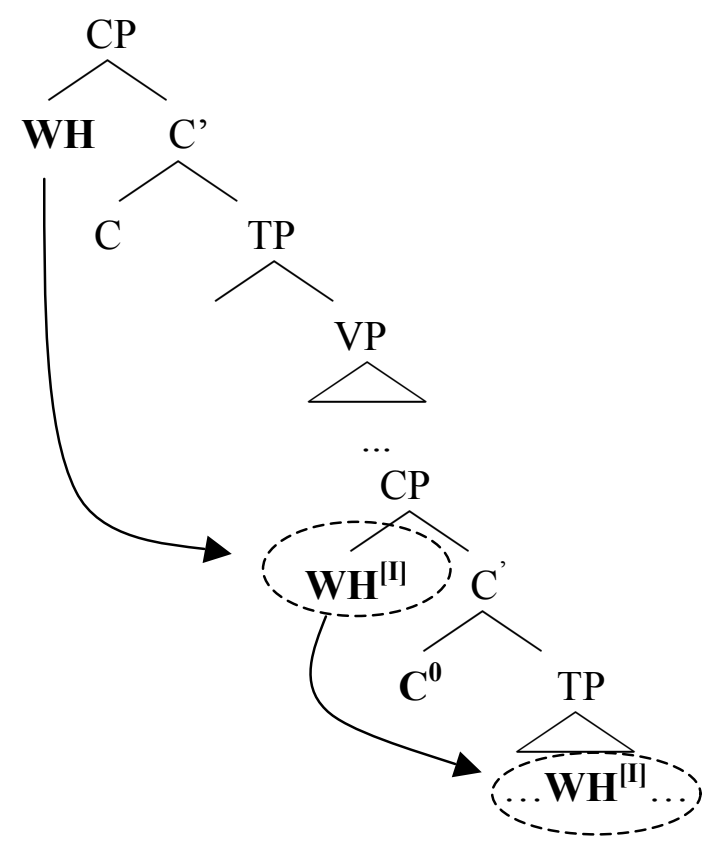

Morphology: Incorporation of the intermediate WH by M-merger

(73)

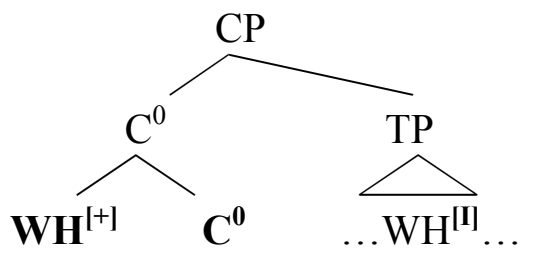

If the relevant operation were Fusion we would obtain the same result as Nunes, assuming that the wh-copy fuses on $\mathrm{C}$ and not the other way around; otherwise, the $[\mathrm{I}]$ feature would project at the $\mathrm{MWd}$ level rendering such a feature visible for VIB.

This is an important difference between both systems. As Nunes observes, the Fusion assumption is not a trivial one:

[...] I am not assuming that every head adjunction leads to morphological reanalysis; otherwise standard verb movement to $\mathrm{T}$, for example, would necessarily involve verb duplication.

[Nunes 2004: 169, footnote 40] 
Does the I-Assignment system predict multiple realizations of head copies because of standard V movement to T? The answer is no. Let's see why. Assume first that head movement proceeds by head adjunction in the syntax:

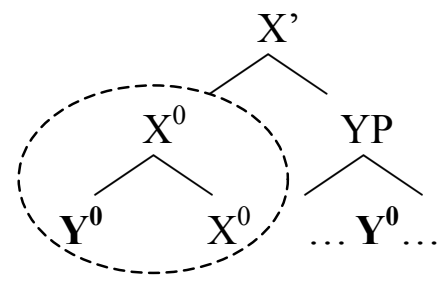

In this configuration, lower $\mathrm{Y}^{0}$ cannot be $I$-assigned because of a failure of the c-command condition in (54ii). Saab (2008) proposes that head chains are $I$ assigned at PF in another cycle of I-Assignment (see 53). Now, in the best case the conditions for morphological I-Assignment are not stipulated but follow from independent factors. I contend, then, that these conditions are indeed the same that apply for post-syntactic displacement, namely, immediate locality and adjacency, as defined in Embick \& Noyer (2001) for accounting for different varieties of morphological displacements. In other words, movement and deletion at PF obey the same locality conditions, a welcome result, if correct. Here is the relevant definition for Morphological I-Assignment:

(75) Morphological I-Assignment (Head Ellipsis):

Given a Morphosyntactic Word (MWd) $\mathrm{Y}^{0}$, assign a [I] feature to $\mathrm{Y}^{0}$ if and only if there is a node $\mathrm{X}^{0}$ identical to $\mathrm{Y}^{0}$ contained in an MWd adjacent or immediately local to $\mathrm{Y}^{0}$.

(where the notion of containment is reflexive)

Immediate locality is the relation between a head and the head of its complement. It is the structural condition that applies for affix hopping in English, where the relation between the affix and the verbal base can be interrupted by adverbs:

(76) John [TР $t\left[{ }_{\nu \mathrm{P}}\right.$ completely destroy-ed the opposition...

[adapted from Embick \& Noyer 2001: 585]

Other cases of affixation at PF require adjacency between the targets of the movement:

(77) a. Mary is the mo-st amazingly smart person ...

b. *Mary is the $t$ amazingly smart-est person ...

[Embick \& Noyer 2001: 565]

The difference between these two kinds of affixation processes can be accounted for if post-syntactic operations can take place before or after the introduction of linearization statements. Once a linearization statement is introduced in the structure, adjacency becomes a relevant condition for displacement. We arrive thus at the following ordering of PF operations. 
(78)

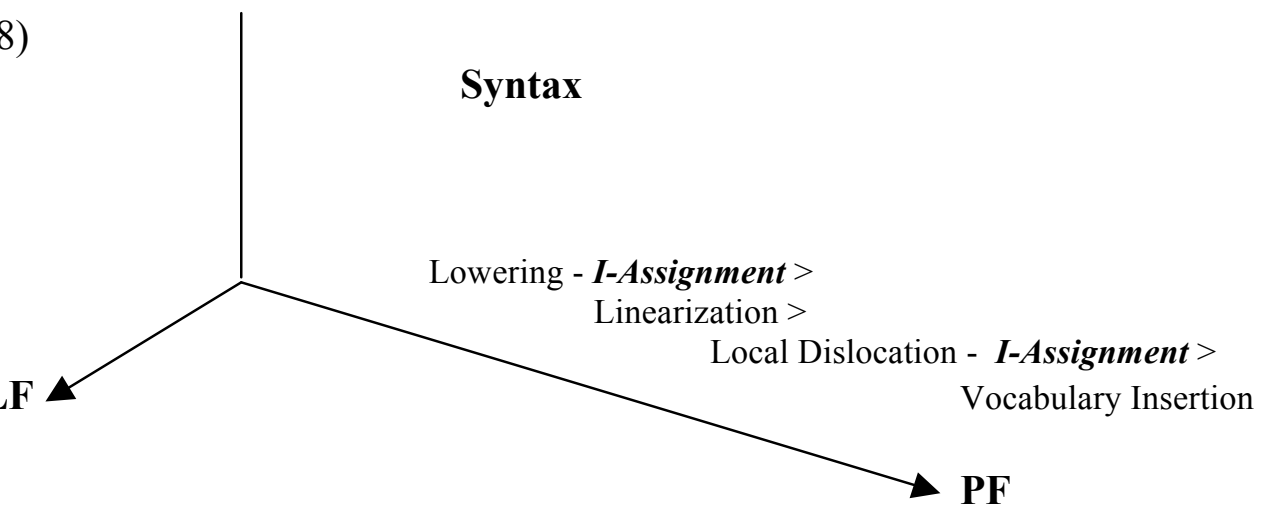

We see now that standard head movement feeds morphological IAssignment for head copies at PF once identity is satisfied:

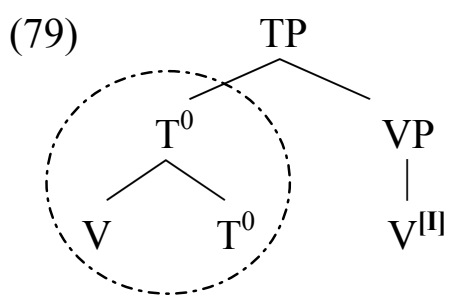

The system sketched here predicts that multiple copy realization can be the result of different factors. First, with reference to heads, it predicts that a head copy is realized whenever the conditions in (75) are not met. Second, it also predicts that copy pronunciation might arise as a result of the Sub-Word Deletion Corollary. As we will see, these two factors underlie different varieties of verbal doublings in Spanish and Portuguese. In the next section, I restrict my attention to the anti-adjacent requirement in Rioplatense verbal doubling. Recall (22), repeated below:
a. Vino Juan, vino.
came J. came
'John came!'
b. *Juan vino vino.
c. $\mathrm{V}_{1} \mathrm{XP}, \mathrm{V}_{2}$.

Any theory of copy pronunciation must have the tools for accounting for this type of effects. As argued in section 4, the $I$-Assignment system has already the answer to anti-adjacency in verbal doubling. I will also demonstrate that Fusion cannot be the cause behind head pronunciation. Yet, the theory would not be complete if was not able to account for the opposite pattern, namely, verbal duplication under adjacency. Consider again the example in (3) from European Portuguese: 


$$
\begin{aligned}
& \text { A: O João não comprou o carro, pois não? } \\
& \text { the J. not bought the car, pois NEG } \\
& \text { 'John didn't buy the car, did he?' } \\
& \text { B: Comprou, comprou. } \\
& \text { bought, bought } \\
& \text { 'Yes, he DID.' }
\end{aligned}
$$

Again, the I-Assignment system handles this type of local doubling without altering the essential analysis already proposed in Martins (2007). I address this issue in section 5 .

\section{Deriving anti-adjacency effects in Rioplatense Spanish verbal doubling}

Let's start this section with more examples illustrating anti-adjacency in Rioplatense Spanish verbal doubling and comparing them with regular bisentential structures involving two adjacent verbs. ${ }^{7}$ As expected, two different verbs in two different sentences should not produce anti-adjacency effects (examples from Saab 2011):

Verbal doubling:

A: ¿Quién corre esta tarde?
who runs this afternoon
'Who runs this afternoon?'
B: Corre Juan, corre.
runs J. runs
B': *Juan corre, corre.
J. runs $\quad$ runs
'John runs!'
A: ¿Quién vino? who came
'Who came?'
B: Vino Juan, vino. came J. came
B': *Juan vino, vino. J. came came 'John came!'

(84) A: ¿Qué saco? what take-out.1SG 'What do I take out?'
B: Sacá la basura, sacá. take-out the rubbish take-out.2SG

${ }^{7}$ This requirement also applies in Italian, as the following example from Gullì (2003) shows:

(i) Mangia la pizza,mangia.

eats the pizza eats

'He really is eating the pizza.'

(ii) *Mangia, mangia.

[Gullì 2003: 31] 


$\begin{array}{clll}\text { B': *La } & \text { basura } & \text { sacá, } & \text { sacá. } \\ \text { the } & \text { rubbish } & \text { take-out } & \text { take-out.2SG } \\ \text { 'Take the rubbish out!' } & & \end{array}$

\section{Bi-clausal structures:}
A: ¿Hiciste el trabajo hoy?
did.2SG the work today
'Did you do the work today?'

$\begin{array}{lllll}\text { B: Hoy } & \text { no, no lo } & \text { hice. } & \text { Lo } \\ \text { today } & \text { no not ACC.3SG.M } & \text { did:1SG } & \text { ACC.3SG.M } \\ \text { hice } & \text { ayer. } & & \\ \text { did:1SG } & \text { yesterday } & & \\ \text { 'I did not do it today. I did it yesterday.' } & \end{array}$

(86) A: ¿Vino Juan?

came J.

'Did Juan come?

B: Sí, Juan vino. Vino hace una hora. yes J. came came does one hour

'Yes, he did. He came one hour ago.'
A: ¿Estaba Juan en la fiesta?
was J. in the party
'Was Juan at the party?'

B: Sí, Juan estaba. Estaba junto con María.

yes J. was was together with $M$.

'Yes, Juan was. He was together with María.'

Under the I-Assignment framework, the analysis suggested in (29), and repeated below, should be enough to account for these anti-adjacency effects:
a. Compró el auto, compró.
bought the car, bought.

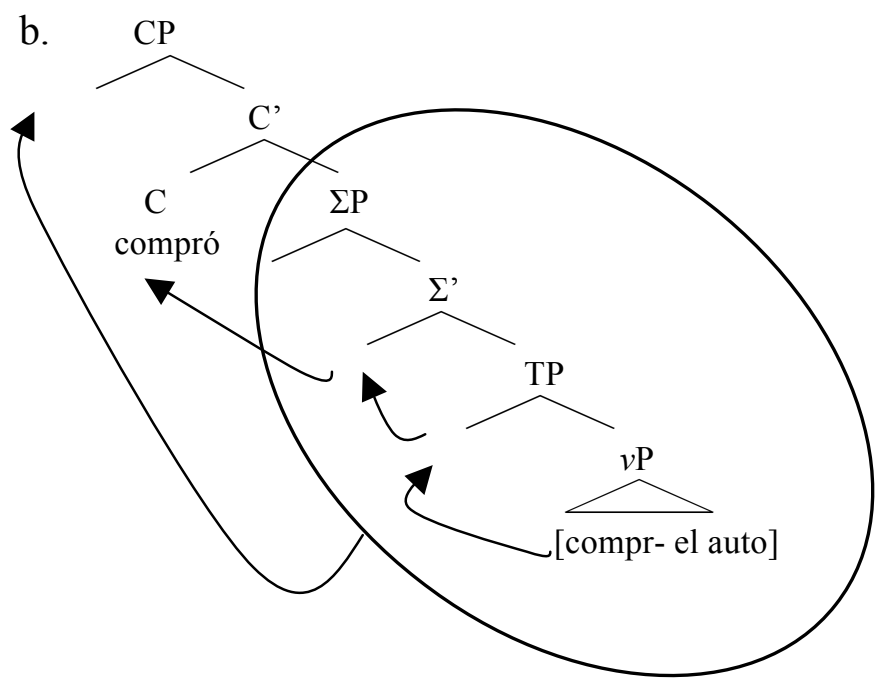


Let's now further elaborate on the details. Adapting Martins' (2007) analysis for verbal doubling in European Portuguese (see section 5), I assume that verbal duplication requires an instance of remnant movement plus verb movement to some position in the left periphery (see 89). Verbal movement is T-to- $\Sigma$-to-C and the remnant that moves (by hypothesis to Spec,CP) is $\Sigma$ P. Given that this movement is phrasal, it triggers an instance of $I$-Assignment under c-command. Cyclic verbal movement, instead, triggers different instances of morphological $I$ Assignment under immediate locality. Consider the tree for a sentence such as Vení acá, vení Lit: 'come here, come':

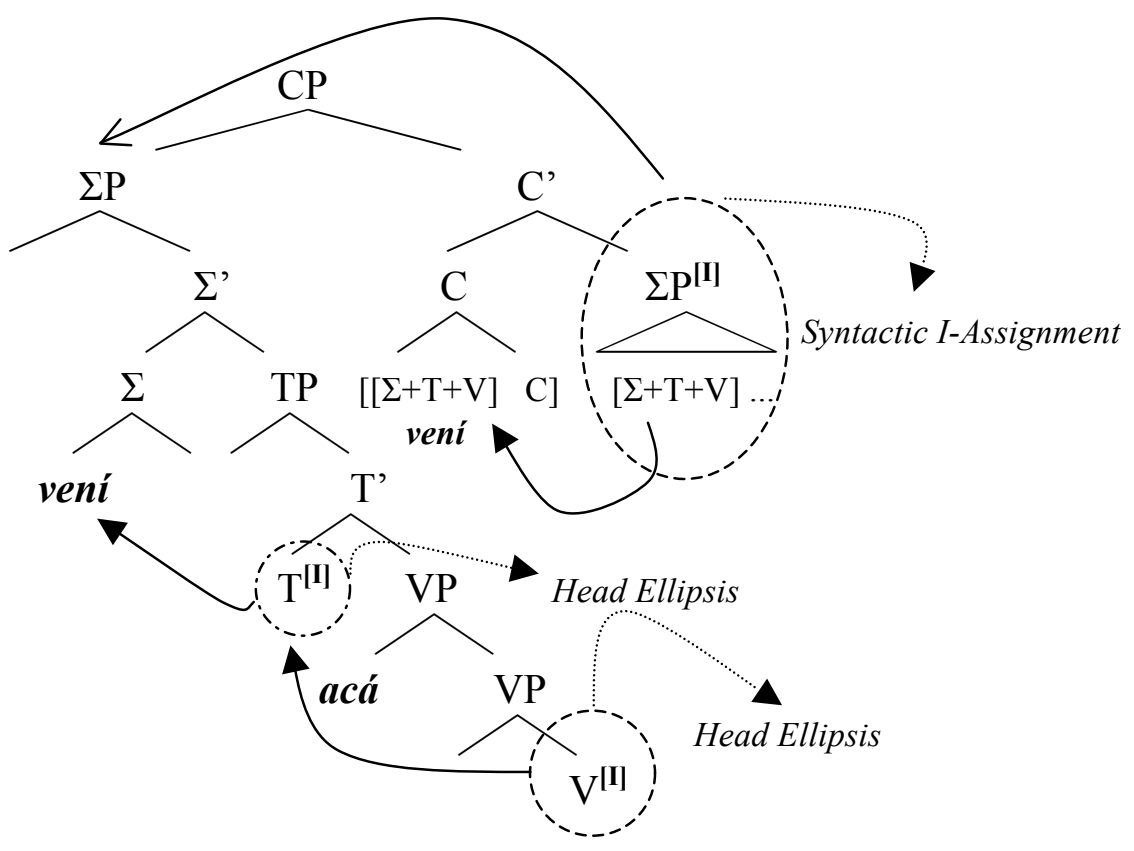

As extensively argued in Saab $(2008,2011)$, the lower verbal head in C cannot be deleted either under immediate locality, because it is not in the head of the complement of the higher copy, or adjacency, because in this particular case the locative acá intervenes. The abstract structure for a case of anti-adjacent verbal doubling after linearization of MWds is as follows:

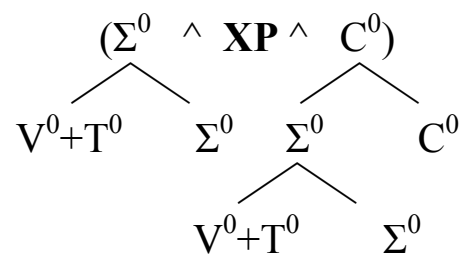

Evidently, the presence of an intervening $\mathrm{X}(\mathrm{P})$ is crucial, as its absence would make $V_{1}$ and $V_{2}$ adjacent. Under this scenario, one of the two verbs would be $I$-assigned. This explains why all the versions of verbal doubling with adjacent verbs are strongly ungrammatical: the system just does not generate these sentences. In order to decide which of the two verbs is indeed deleted we should take a look at the details of some possible adjacent counterpart of (90): 
(91)

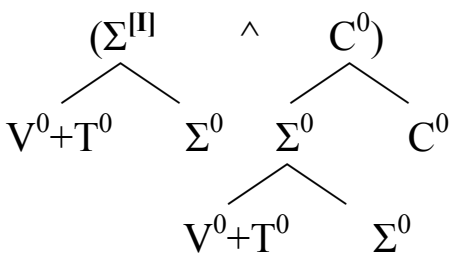

If our basic syntactic and morphological derivation for verbal doubling in Rio de La Plata Spanish is correct, then it has to be the case that I-Assignment only targets the left copy of the $\Sigma^{0}$ complex head, because it is the only one that complies with the requirements of Head Ellipsis under adjacency:

(92) Morphological I-Assignment (Head Ellipsis):

Given a Morphosyntactic Word (MWd) $\mathrm{Y}^{0}$, assign a [I] feature to $\mathrm{Y}^{0}$ if and only if there is a node $\mathrm{X}^{0}$ identical to $\mathrm{Y}^{0}$ contained in an MWd adjacent or immediately local to $\mathrm{Y}^{0}$.

(where the notion of contained is reflexive)

The analysis I am defending for head copy pronunciation in Río de La Plata Spanish has at least two obvious advantages when compared with Nunes' system. First, it has an account for anti-adjacency effects, a fact pending an explanation in Nunes' approach. Second, it dispenses with the Fusion assumption as a pre-requisite for copy pronunciation. This is not only a theoretical advantage, but it also seems to have interesting empirical consequences. Recall that verbal doubling in the dialect under consideration also requires clitic duplication whenever the verb on the left is associated with a clitic or a clitic cluster:

a. Lo atamos con alambre,

CL.ACC.3.MASC.SG tie.1PL with wire

*(lo)

atamos.

CL.ACC.3.MASC.SG tie.1PL

'We tie it with wire!'

$\begin{array}{lllll}\begin{array}{l}\text { Me } \\ \text { CL.DAT.1SG }\end{array} \quad \text { CL.ACC.3.MASC.SG } & \text { gave } & \text { Pedro, me } \\ \text { lo } & \text { dio. } & & \\ \text { CL.ACC.3.MASC.SG gave } & & & \\ \text { 'Pedro gave it to me!' } & & \end{array}$

As already explained in section 2, clitic duplication occurs because once the clitic is attached to the verbal complex head, it is swept away by this head on its way to $\mathrm{C}^{0}$.

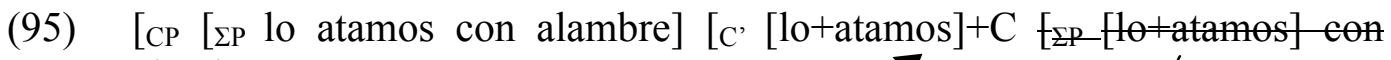
alambre] ]

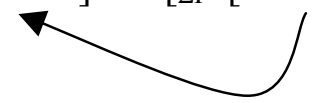

For my system to work in this and related cases, we must assume that clitic clusters are part of the complex head containing the verb to be duplicated. So, we suppose that the tree in (96) is the correct abstract structure underlying both CL-verb complexes in cases like (95): 
(96)

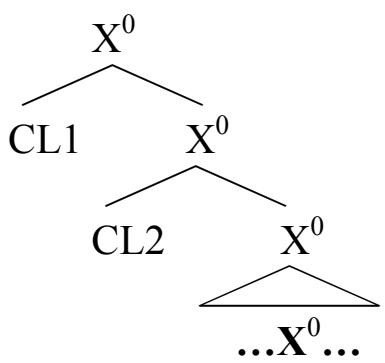

If this structure underlies verbal duplications of the relevant kind, then Nunes' account in terms of Fusion looks a bit suspicious. Evidence for Fusion in cases with proclisis seems hard to obtain given that insertion proceeds in a transparent way for every terminal node provided by the syntax. Positing Fusion requires strong empirical support as, for instance, morpho-phonological opacity effects, which is not the case here. In the next section, this argument will be further elaborated in connection with Martins' (2007) approach to local doubling in Portuguese.

Yet, in view of the many analyses available for clitic clusters in the literature, one may object that the structure in (96) is in need of some independent motivation. Fortunately, there is such evidence.

A fact that convincingly shows that the two duplicated verbs are indeed complex heads is the behavior of the intensifier prefix re in Río de La Plata Spanish. Leaving aside some details, this intensifier re can combine with any type of grammatical category (e.g., re-lindo 're-nice', un re-auto 'a re-car', re-canté 're-sang.1SG', re-lejos 're-far', etc.). The meaning of the whole structure will depend precisely on the relevant category (e.g., re lindo 're-nice' means very nice, but re-canté 're-sang' means I sang a lot; cf. Kornfeld \& Kuguel 2013 for details). Kornfeld \& Kuguel also notice that re has two important properties: (i) it can occur in isolation as in (97), and (ii) it can modify phrases as in (98):
A: ¿Es lindo/ is nice
te
gusta/
venís?
$\mathrm{B}:$ Re.

you like / come.2SG
'Yes, it is / I do / I do!'
a. Juan
re
[jugó y
trabajó].
J.
RE played and
worked

'John played and worked a lot.' / 'John did play and work!'
b. re [lindo e inteligente]
$\mathrm{RE}$ nice and intelligent
c. un gato re [cazador
a cat RE hunter
de ratones]
of mice

[Kornfeld \& Kuguel 2013: 32]

Kornfeld \& Kuguel observe that many of the key properties of the intensifier re would be accounted for if $r e$ is analyzed as a phrasal clitic, which only attaches to maximal categories (i.e., re-XP). 
If our claim that V2 in a verbal doubling construction in Rioplatense Spanish is on the right track, we predict that the intensifier $r e$ cannot be duplicated in any of the two verbs. This is borne out:
a. Voy al cine, voy.
go.1SG to.the cinemago.1SG
'I go to the cinema!'
b. *Re-voy al cine, re-voy. RE-go.1SG to.the cinema RE-go.1SG

Even more interestingly, this contrasts with the head prefix re in cases like rehacer 're-do', where reduplication is allowed. Compare in this respect (100a), where verbal doubling is licensed with the head prefix re, with (100b), an illegitimate instance of verbal doubling with phrasal re. In both cases, the hosting verb is exactly the same.
a. Rehice el trabajo, rehice. rewrote the work rewrote 'I rewrote the work!'
b. *Re-hice el trabajo, re-hice. RE-did the work RE-did

It seems then that we have a robust indication for the head status of the lower verbal copy. ${ }^{8}$ This is not a minor point given that remnant movement alone cannot be the cause behind duplication. In fact, the I-Assignment system predicts a difference between heads and phrases when it comes to evaluating different copy realization scenarios. Concretely, if a phrasal copy vacates a remnant constituent then the copy in the constituent that moves as remnant must not be pronounced under normal circumstances. This is because of the c-command condition on I-Assignment, which is operative in the case of phrasal copies (cf. condition 54ii):

${ }^{8}$ This leads to the conclusion that in cases like (1), where there is a modal verbal phrase involved, the auxiliary and the verbal infinitive must also be analyzed as a morphological complex head, not an implausible analysis (see Roberts 1997):

(i) Deben ser los gorilas, deben ser.

must be.INF the gorillas must be.INF

[from an old popular song]

This, in principle, blocks the recent objection raised by Jokilehto (2016), according to whom my analysis cannot be extended to Roman Italian verbal doubling involving verbal sequences:

$\begin{array}{llll}\text { (ii) Hai } & \text { fatto bene, hai } & \text { fatto! } \\ \text { have.2SG } & \text { done well have.2SG } & \text { done }\end{array}$

'You did well.'

[Jokilehto 2016: 151]

Beyond discourse-related effects that differentiate Roman Italian from Rioplatense Spanish (see section 1), I do not see essential differences in the formal properties of both languages, at least at a basic descriptive level. In order to validate Jokilehto's objection, it has to be shown that the verbal complexes in (i) and (ii) cannot be analyzed as complex heads at some level of analysis. 


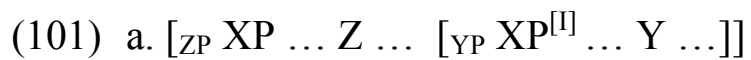

Extracting XP from YP (I-Assignment to lower XP)

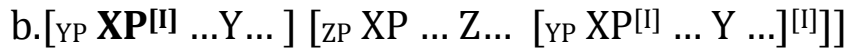

Remnant movement (I-Assignment to YP)

This abstract scenario is factually observed in standard cases of remnant movement:

(102) a. ... and elected John was.

b. [CP [vp elected John $\left.{ }^{[\mathrm{II}]}\right]$ [TP John was [vp elected John $\left.\left.{ }^{[\mathrm{II}]}\right]^{[\mathrm{II}]}\right]$

In turn, remnant movement with a head in place of XP should in principle show copy pronunciation of the left head copy, given that: (i) there is no $I$ Assignment in the syntax for the copies at hand, and (ii) remnant movement bleeds the contexts for morphological $I$-Assignment under immediate locality. As we have seen in this section, this is exactly the pattern observed in Río de La Plata Spanish, but future inquiry is required in order to sustain this observation. ${ }^{9}$

\title{
5. Local and non-local doubling in Romance: the case of Portuguese
}

Let us address now the problem of local vs. non-local doubling in Romance. Recall the basic contrast:

\author{
Río de la Plata Spanish \\ Vino Juan, vino. \\ came J. came \\ 'John came!'
}

(104) European Portuguese

A: O João não comprou o l carro, pois não?
the J. not bought the car, pois NEG
'John didn't buy the car, did he?'
B: Comprou, comprou.
bought, bought
'Yes, he DID.'

[Martins 2007: 81]

Martins proposes that (104B) derives via $\mathrm{V}$-to-T-to- $\Sigma$-to-C movement plus VP-ellipsis (a typical property of this language). $\Sigma$ encodes an affirmative feature and $\mathrm{C}$ an emphasis feature. In turn, morphological Fusion of the verb in $\mathrm{C}$ is responsible for the verbal doubling (see 105). Thus, Martins adopts Nunes' (2004) claim that multiple copy realization is the result of morphological Fusion:

$9 \quad$ As noticed by Muñoz Pérez (2017), there are analyses in the literature that seem to contradict the type of predictions that the $I$-assignment system makes in this particular respect (see, for instance, Wiland 2008). 


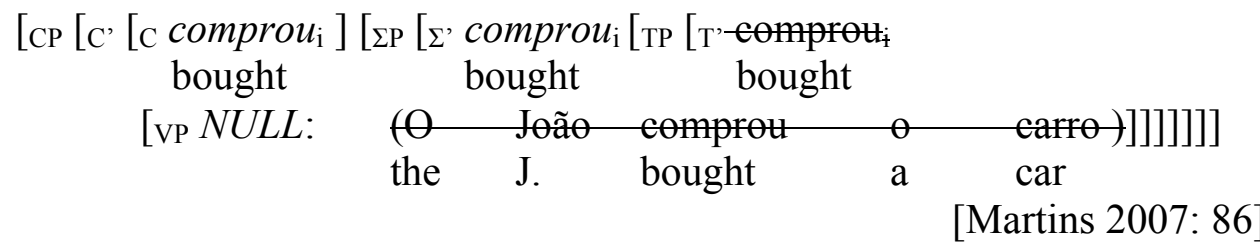

Putative evidence in favor of Fusion comes from the incompatibility of local doubling with complex tenses and clitics:

Future:

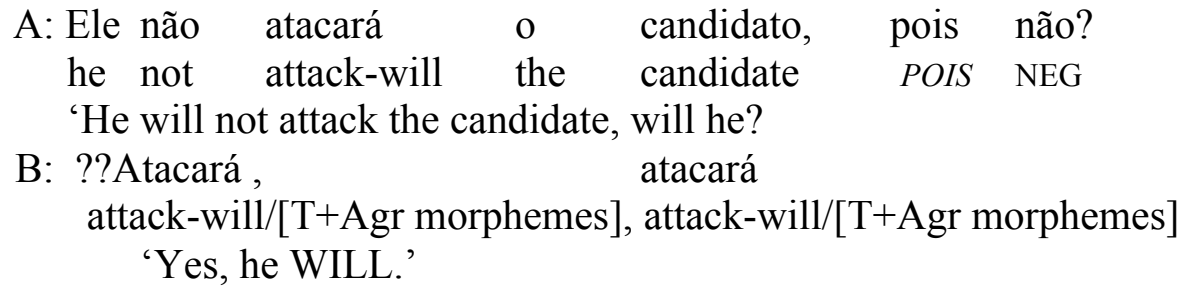

Conditional:
A: Ele não atacaria o candidato, pois não? he not attack-would the candidate POIS NEG 'He would not attack the candidate, would he?
B: ??Atacaria, atacaria attack-would/[T+Agr morphemes], attack-would/[T+Agr morphemes] 'Yes, he WOULD'

[Martins 2007: 108]

\section{Clitics:}

(108)
A: Nãome devolveste o livro que eu
not me returned.2SG the book that I
te emprestei, pois não?
you-DAT lent, POIS NEG
'You haven't returned me the book I lent you, did you?'
B: Devolvi, devolvi.
returned, returned
'Yes, I DID.'
B': *Devolvi-te, devolvi-te.
returned-you, returned-you
B": *Devolvi-to, devolvi-to. returned-you.it, returned-you.it 'Yes, I DID.'

[Martins 2007: 110]

There are some shortcomings with this analysis, though. First, the incompatibility with complex tenses cannot be taken as evidence for Fusion. There is no reason why complex tenses cannot be subject to Fusion and, in fact, an analysis in terms of Fusion has been proposed for the future in Spanish for well-motivated reasons (Oltra-Massuet \& Arregi 2005). Second, the distribution 
of clitics cannot be taken as evidence for Fusion either. Recall that in Spanish clitics must occur with $\mathrm{V}_{2}$ whenever they occur with $\mathrm{V}_{1}$ :

$$
\begin{array}{llll}
\text { a. Lo } & \text { atamos con } & \text { alambre, } & *(10) \\
\text { CL.ACC.3.MASC.SG } & \text { tie.1PL with } & \text { wire } & \text { CL.ACC.3.MASC.SG }
\end{array}
$$
atamos.

tie.1PL

'We tie it with wire!'

Third, the analysis in terms of Fusion cannot account for the antiadjacency effects typically attested in Spanish and Italian:
(110) Río de la Plata Spanish
Vino Juan, vino.
came J. came
'John came!'

\section{(111) Italian}
a. è andato a Parigi, è andato.
is gone to Paris is gone
'He really did go to Paris.' [Gullì 2003: 3]
b. Mangia la pizza, mangia.
eats the pizza eats
'He really is eating the pizza.'

[Gullì 2003: 31]

Therefore, we have to explore an alternative. Concretely, an analysis as the one suggested by Nunes (2004) for similar cases of verbal duplication in Vata (see 112) could raise some interesting consequences if extended to European Portuguese. Regarding Vata, Nunes proposes that there is verb movement to a focus position and then Fusion between these categories. In Saab (2008), this paradigm is reinterpreted in terms of the I-Assignment system. Concretely, verb movement to Foc is enough to account for the basic cases without assuming Fusion. Consider briefly how this analysis proceeds:

(112) Vata

$\begin{array}{llllll}\text { a. } & \overparen{i} & \text { à } & \overparen{i} \text {-dā } & \text { zué } & \text { sàká } \\ & \text { eat } & \text { we } & \text { eat-past } & \text { yesterday } & \text { rice }\end{array}$

'We ATE rice yesterday.'
b. $\quad$ i Ó dā
sàká
eat she/he perf-aux
rice eat

'She/He has EATEN rice.'

[Koopman 1984 apud Nunes 2004: 47]

The associated structures for each of these two examples are, respectively, as follows ( $N O$ and $O K=$ illegitimate and legitimate instance of $I$-Assignment, respectively). 
(113)

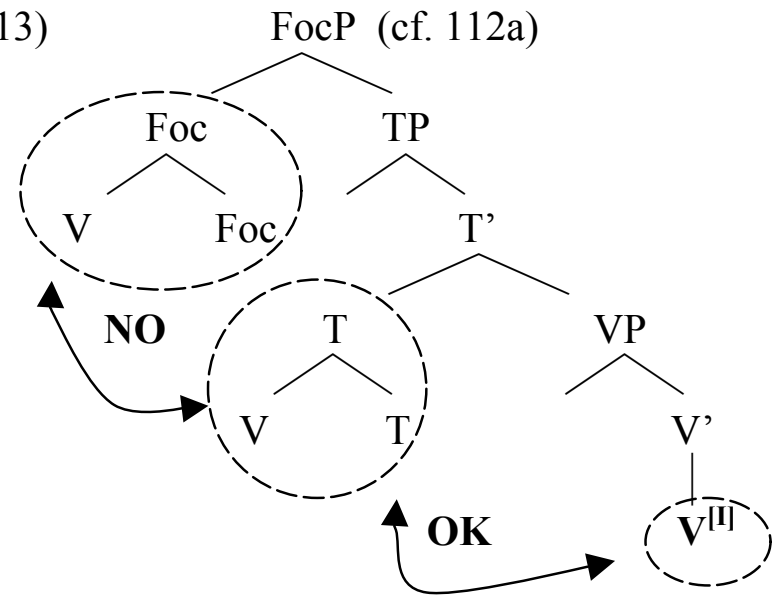

(114)

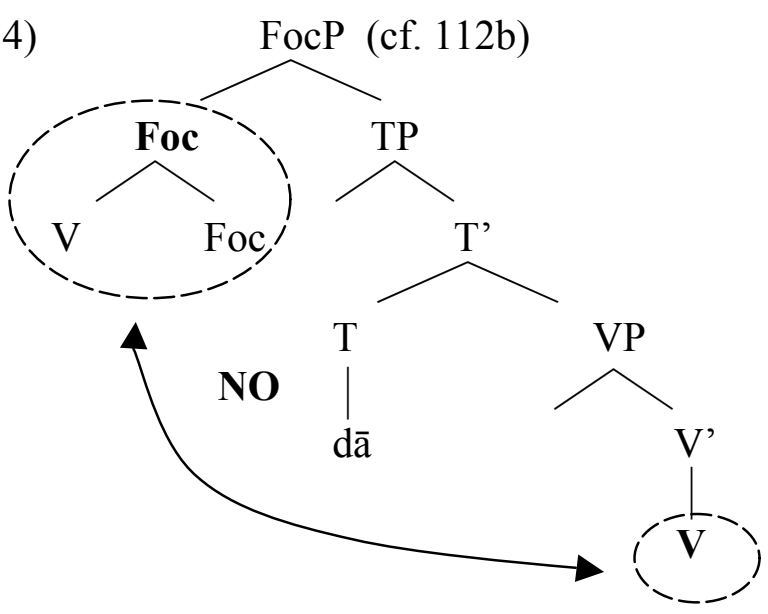

The structure in (113) expresses the impossibility of I-Assignment to the head immediately dominated by Foc, whereas (114) expresses that the requirement of immediate locality is not met between the two verbal copies involved in the structure. The key for understanding (113) is excorporation of $\mathrm{V}$ from T. As discussed in Nunes, excorporation allows us to explain why neither the negation nor temporal particles can occur in these contexts:
a. (*nà') $\overparen{e}$ wà $n a^{\prime}-l e-k a ̄$
$\left({ }^{*} \mathrm{NEG}\right)$ eat they NEG-eat-FUT
'The will not EAT.'
$\begin{array}{cllll}\text { b. } \overparen{i}\left({ }^{*} \text { wa) }\right. & \text { wa } & \overparen{i-w a} & \text { zué. } \\ \text { eat } & \left({ }^{*} T P\right) & \text { they } & \operatorname{eat}(* T P) & \text { yesterday }\end{array}$

'They ATE yesterday.'

[Koopman 1984 apud Nunes 2004: 48]

If the verb moved together with $\mathrm{T}$ on its way to Foc, then I-Assignment would apply to every head below Foc preventing duplication: 
(116)

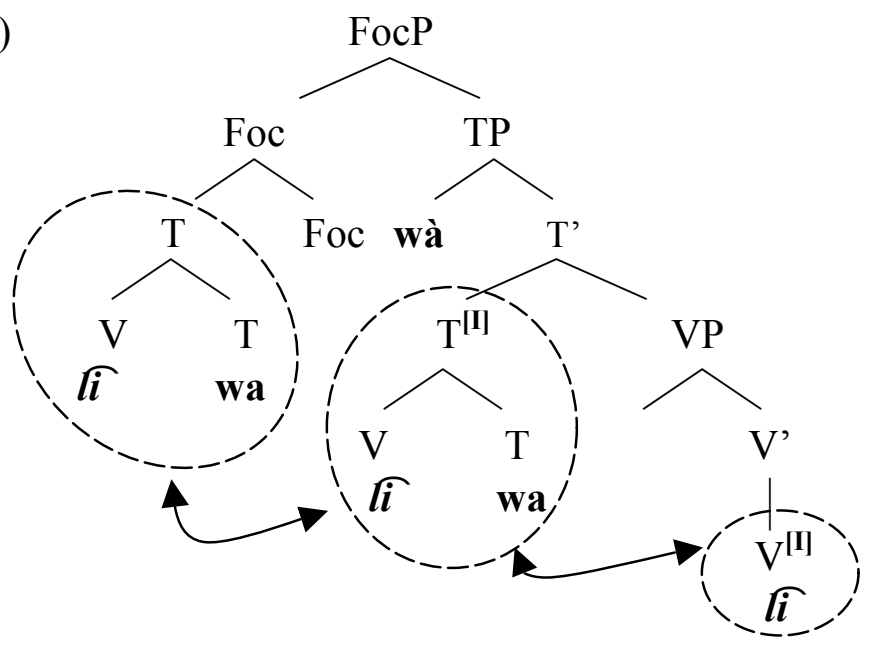

This approach can be extended to verbal duplication in European Portuguese. The difference would be in the fact that in European Portuguese Foc attracts the $\mathrm{T}$ head and every category it contains, leaving $\Sigma$ in situ. That is to say, when $\mathrm{T}$ moves to Foc, the context for applying Head Ellipsis is not met and, as a consequence, Vocabulary Insertion applies both to Foc and $\Sigma$. In turn, the lower heads correctly obtain their [I] feature via immediate locality with their antecedent heads. The following tree illustrates this analysis for a simple case like comprou, comprou Lit:'bought, bought':

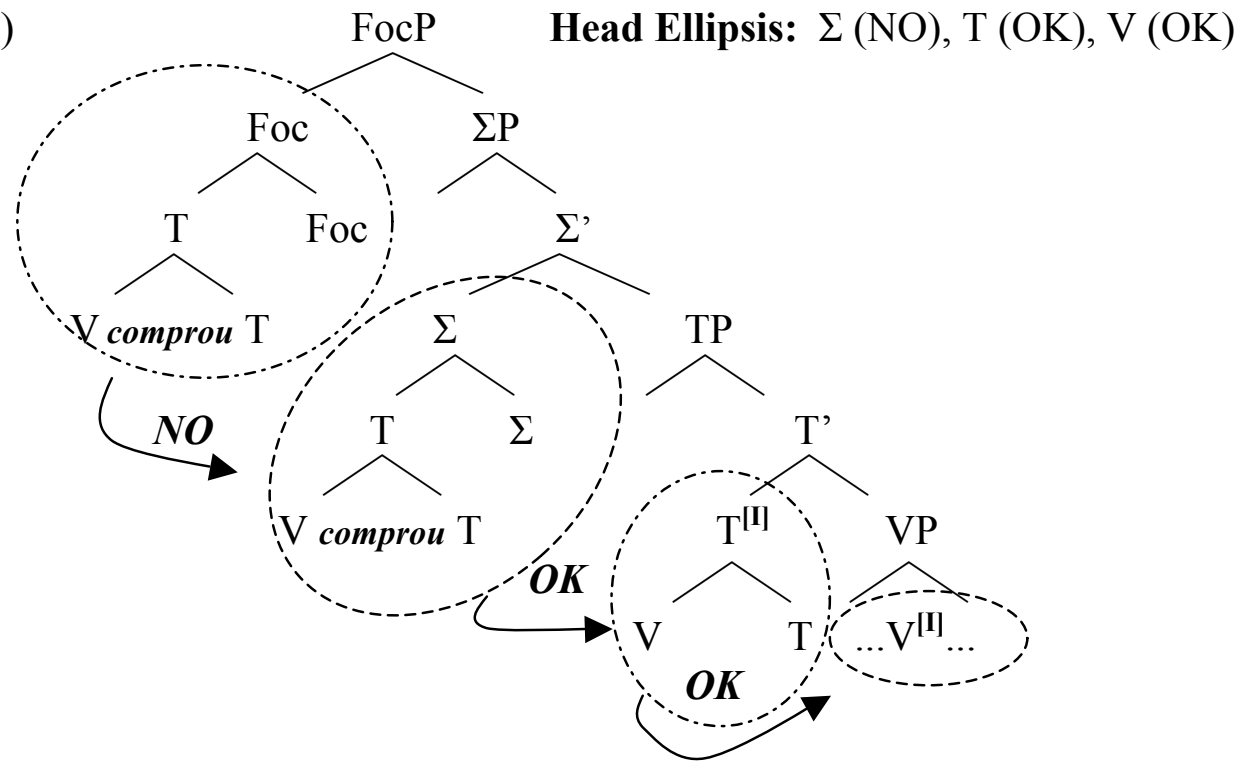

This structure correctly predicts why there are no anti-adjacency effects in European Portuguese. Head Ellipsis cannot take place between $\Sigma$ and Foc because the two Ts are $S W d \mathrm{~s}$ :

(118) Sub-Word Deletion Corollary:

The [I] feature is inert below the MWd level.

A first empirical argument in favor of excorporation comes precisely from the incompatibility of complex tenses in verbal doubling already illustrated in 
(106) and (107). It is well known that both synthetic forms of the future and the conditional both in Spanish and Portuguese derive from an analytical form which included the form of the infinitive plus the auxiliary haber 'to have'.

(119) amar+é, as, emos, etc...

Spanish

love.INF + have.1SG, have. $2 \mathrm{SG}$, have.1PL, etc...

Therefore, let us assume the following syntax for the future (the same for the conditional), where the feature [posterior] in the lower tense node $\left(\mathrm{T}^{2}\right)$ indicates the way in which the event must be interpreted with respect to the temporal anchor that the higher tense node introduces $\left(\mathrm{T}^{1}\right)$. In the case of the future, the main event is then read as posterior to the present and as posterior to the past in the conditional (not illustrated here). In both cases, the feature posterior is realized as $-r$ at the point of $\mathrm{VI}$ :

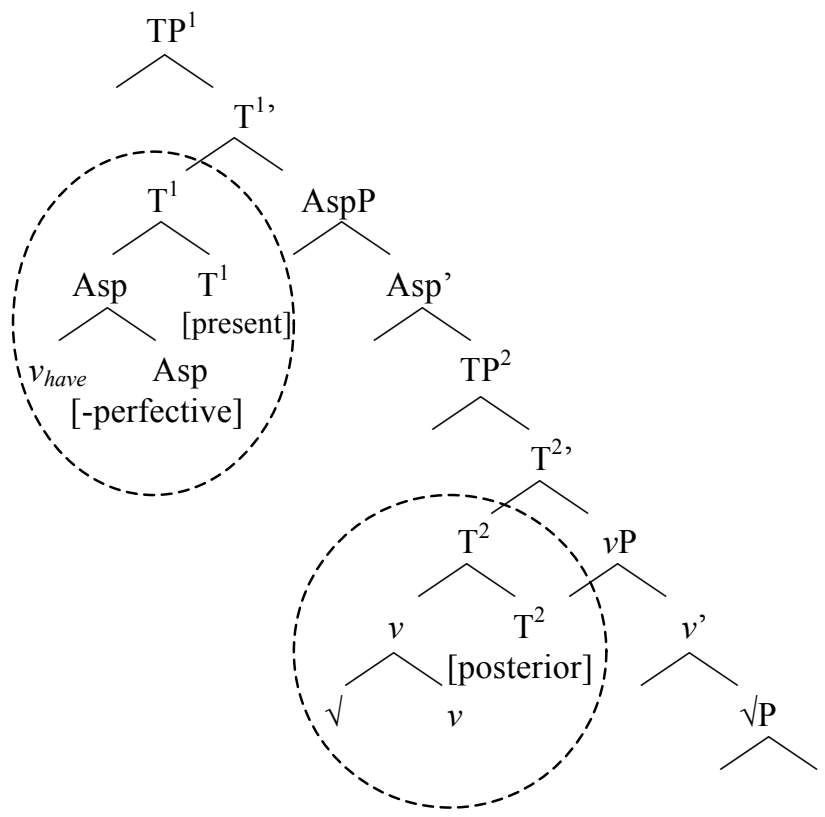

In both modern Spanish and European Portuguese, the form of have incorporated onto $T^{1}$ lowers to $T^{2}$ (Kornfeld 2005 and Saab 2008) whenever $T^{2}$ encodes [posterior] (i.e., the conditional and the future): ${ }^{10}$

${ }^{10}$ Mesoclisis in Portuguese provides further evidence for a morphological analysis (see also Kornfeld 2005 for old Spanish):

(i) Mesoclisis:

a. Ele ataca-o se puder.

he attack-present-indicative-him if can

'He will attack him if he can.'

b. Ele atacá-lo-á se puder.

he attack-him-will/[T(present)+Agr morphemes] if can

'He will attack him if he can.'

c. Ele atacava-o se pudesse.

he attack-imperfect-indicative-him if could

'He would attack him if he could.' 
(121) Lowering rule:

$$
\left.\left[\mathrm{T}^{1} \mathrm{~T}^{1}\right]+\left[\mathrm{T}^{2} \mathrm{~T}^{2}\right] \rightarrow\left[\mathrm{T}^{2}\left[\mathrm{~T}^{2}\right]+\left[\mathrm{T}^{1}\right]\right] / \mathrm{T}^{2}{ }_{\text {posterior }}\right]
$$

With this in mind, the marginality in (106B) and (105B) is accounted for under the excorporation analysis. Concretely, if $\mathrm{T}^{1}$ excorporates the structure in (122) is obtained:

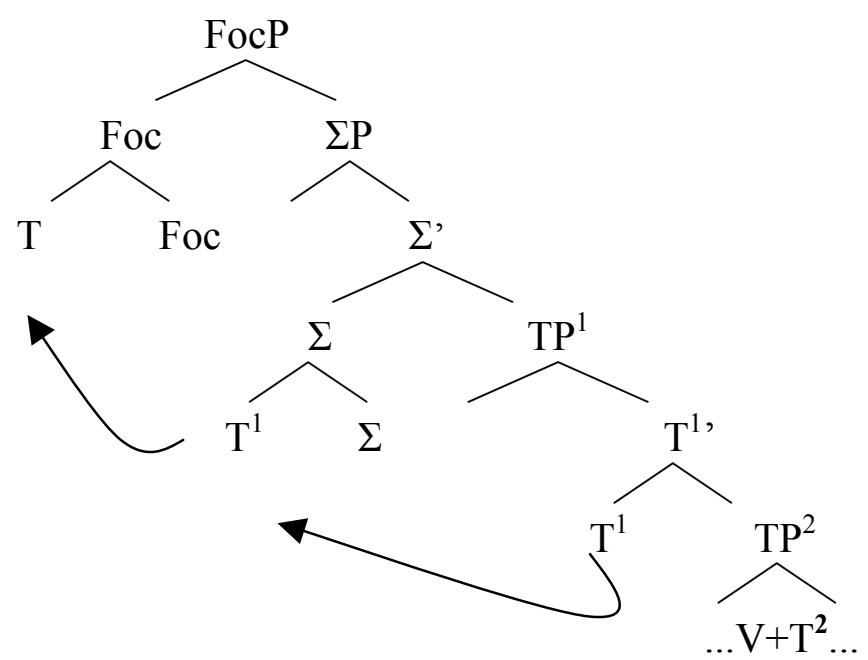

This configuration does not produce verbal doubling in the first place. The only possible output should be as in (123), an ungrammatical option, because of the stranded affix $-a$ :

$$
\begin{array}{cl}
* \text { *a } & \text { atacará } \\
\text { has } & \text { attack.has }
\end{array}
$$

Consider, finally, the distribution of clitics in contexts of verbal doubling in European Portuguese:

$\begin{array}{clllll}\text { A: Não me } & \text { devolveste } & \text { o } & \text { livro que } & \text { eu } \\ \text { not me } & \text { returned.2SG } & \text { the } & \text { book that } & \text { I } \\ \text { te } & \text { emprestei, } & \text { pois } & \text { não? } & & \\ \text { you-DAT } & \text { lent, } & \text { POIS } & \text { NEG } & & \end{array}$

'You haven't returned me the book I lent you, did you?'

B: Devolvi, devolvi. returned, returned 'Yes, I DID.'

B': *Devolvi-te, devolvi-te. returned-you, returned-you 'Yes, I DID.'

d. Ele atacá -lo-ia se pudesse. he attack-him-will/[T(past)+Agr morphemes] if could 'He would attack him if he could.' 


$$
\begin{aligned}
& \text { B': *Devolvi-to, devolvi-to. } \\
& \text { returned-you.it, returned-you.it } \\
& \text { 'Yes, I DID.' }
\end{aligned}
$$

[Martins 2007: 110]

A way to account for the different distribution of clitics in verbal doubling for Río de La Plata Spanish and European Portuguese is to assume that verbal movement in European Portuguese reaches a higher position than in Spanish (Martins 1994). Verbal movement is then followed by ellipsis of the remnant constituent in Portuguese:

\section{Devolvi, [devolvi Łxp -...CL ...}

This analysis maintains the essential assumptions in Martins'. The only difference is how high verb movement goes. Notice that an advantage of both analyses is that they can explain why neither Spanish nor Italian has local doubling: both languages lack V-stranding ellipsis (Goldberg 2005), an option largely attested in Portuguese.

\section{Summary of findings and further directions}

I have given an answer to the questions that have guided this paper:

(Q1) On the basis of what empirical evidence can we tell whether or not a given doubling phenomenon is the result of copying the same syntactic object?

(Q2) Under what conditions does copy pronunciation arise as a grammatical option?

As for (Q1), the evidence presented here allows us to conclude that verbal doubling in Río de La Plata Spanish is a clear instance of verbal duplication, whereas $v \mathrm{P}$-topicalization is a case of base-generation (in consonance with Cable 2004 and pace Vicente 2007, 2009).

Then, I have provided a remnant movement analysis for verbal doubling in Spanish along the lines proposed in Martins (2007) and related work. However, I have shown that morphological Fusion is not responsible for copy pronunciation. Anti-adjacency effects in Río de La Plata Spanish (and Italian) show that adjacency is one of the causes of head deletion at PF. Given that adjacency is not found in verbal doubling environments, one of the lower copies of the verbal chain must be pronounced. This gives us an answer to (Q2). Cases of verbal doubling under adjacency (European Portuguese) follow from the Sub-Word Deletion Corollary.

Two important theoretical consequences are worth mentioning before closing. First, as mentioned, the I-Assignment system looks for a unification of different elliptical phenomena (ellipsis, null subjects and copy deletion) under the same underlying mechanism. The differences among these varieties of ellipsis follow from the architecture of the grammar I have adopted (Distributed Morphology). If the conditions for morphological I-Assignment discussed here are 
empirically adequate, then movement and deletion after syntax can also be unified under an integral theory of the syntax-morphology interface (Embick \& Noyer 2001). Second, the varieties of verbal doubling explored may also shed light on the theory of linguistic variation. If I am on the right track, what verbal doubling across Romance illustrates is the need for taking seriously the microparametric approach defended in Kayne (2005), according to which movement and silence are the only possible causes of variation within and across languages.

However, this research leaves open many important issues concerning the nature of the (micro)parameters involved in the constructions discussed so far. We would like to know, for instance, what underlies the difference between Río de La Plata Spanish and other dialects that lack this type of verbal doubling. Second, I have provided some possible correlations in order to distinguish adjacent vs. anti-adjacent doublings in European Portuguese and Río de La Plata Spanish, respectively. Yet, I have remained silent with respect to some crucial discourse-related differences (see section 1). As for the first issue, the difference between Río de La Plata Spanish and other Spanish dialects, I was not able to find any "dramatic" microparameter. The term "dramatic" applied to parametric theory is borrowed from Kayne (2005):

It has occasionally been thought that the term "parameter" itself should only be used when there is such a notable or "dramatic" range of effects. I will not, however, pursue that way of thinking here. In part that is because what seems dramatic depends on expectations that may themselves be somewhat arbitrary.

[Kayne 2005: 278-279]

In a broad sense, we understand that a (micro)parameter is dramatic when presence or absence of a given formal property in a language/dialect erodes certain active linguistic sub-system of the languages/dialects under consideration. As argued by Kayne, linguists are usually concerned with this type of dramatic aspects of language change, but linguistic diversity is also the byproduct of less dramatic situations. It would be plausible that the formal properties (discourserelated features, perhaps) that make verbal doubling available in Rioplatense Spanish do not produce any evident erosion in any other sub-system of the language (say, the left periphery). At the present, I have no cue whether verbal doubling of the Rioplatense type is the surface result of any parametric drama. Relevant linguistic correlations (if any) should inform us more in this respect.

Similar considerations apply when it comes to trying to figure out why non-local doubling in European Portuguese is restricted to emphatic answers like the ones illustrated in (4B) and repeated below:

\begin{tabular}{|c|c|c|c|}
\hline $\begin{array}{l}\text { A: Ele não } \\
\text { he not bo } \\
\text { 'He didn't bu }\end{array}$ & $\begin{array}{l}\text { ou } \\
\text { it } \\
\text { car. }\end{array}$ & $\begin{array}{l}\mathrm{O} \\
\text { the }\end{array}$ & $\begin{array}{l}\text { carro. } \\
\text { car }\end{array}$ \\
\hline $\begin{array}{l}\text { B: Ele comprou } \\
\text { he bought } \\
\text { 'He did buy th }\end{array}$ & $\begin{array}{l}\text { o } \\
\text { the } \\
\text {.' }\end{array}$ & $\begin{array}{l}\text { carro, } \\
\text { car, }\end{array}$ & $\begin{array}{l}\text { comprou. } \\
\text { bought }\end{array}$ \\
\hline
\end{tabular}

[Martins 2007: 81] 
Martins $(2007,2013)$ provides many interesting possible correlations linked to the grammar of polarity in European Portuguese and other Romance languages. Yet, I have argued that Martins' analysis, which is illustrated in (127), is essentially correct for Rioplatense Spanish:

$$
\begin{aligned}
& {\left[\mathrm { CP } [ \Sigma \mathrm { P } \text { ele comprou } { } ^ { \mathrm { i } } \mathrm { o } \quad \text { carro } ] ^ { \mathrm { k } } \left[\mathrm { C } ^ { \prime } [ \mathrm { C } \text { comprou } ^ { \mathrm { i } } ] \quad \left[\Sigma \mathrm{P}-\mathrm{ele}^{\mathrm{j}}\right.\right.\right.} \\
& \text { he bought the car bought he }
\end{aligned}
$$

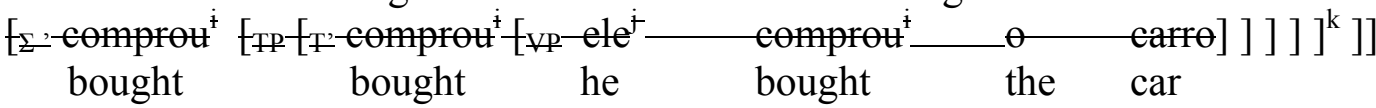

[Martins 2007: 87]

Evidently, if my claim is correct, the difference between both languages should be located on the semantic and formal properties of the $\mathrm{C}$ head. According to Martins, $\mathrm{C}$ and $\Sigma$ encode features related to the grammar of emphatic polarity. In order to get a positive denial like (126B) Martins assumes that the features [reverse] and [affirmative] (see Farkas \& Bruce 2009) are located on C and $\Sigma$, respectively. Formally, this is expressed through head movement from $\Sigma$ to $\mathrm{C}$ and remnant movement of the entire $\Sigma \mathrm{P}$ as illustrated in (127). She further argues that "only languages that independently allow verb movement to $\Sigma$ and verb movement to C display the verb reduplication strategy" (Martins 2013: 100). Yet, verb movement to $\Sigma$ is allowed in languages like Spanish, at least in some restricted configurations (imperatives, Laka 1990). On the other hand, allowance of verb movement to $C$ is just a stipulation given that $\mathrm{C}$ is a label for some of the categories available in the left periphery. Most importantly, Rioplatense Spanish and (Roman) Italian indeed license verbal doubling of the anti-adjacent type even with the aforementioned discourse-related differences (see section 1). In principle, nothing in the formal system prevents feature variation in the relevant nodes (i.e., $\mathrm{C}$ and $\Sigma$ ).

As already mentioned, Rioplatense Spanish allows for verbal doubling in a broad set of situations and, although marked, negative doublings are also attested in oral corpus, an impossible option in European Portuguese: ${ }^{11}$

$\begin{array}{llllll}\text { No } & \text { me } & \text { dieron } & \text { una } & \text { puta } & \text { foto, } \\ \text { no } & \text { CL.ACC.1SG } & \text { gave.3PL } & \text { a } & \text { fucking } & \text { picture } \\ \text { no } & \text { me } & \text { dieron. } & & & \\ \text { no } & \text { CL.ACC.1SG } & \text { gave.3PL } & & \\ \text { 'They didn't give a fucking picture!' } & \end{array}$

[https://www.youtube.com/watch?v=8TG47xYS_ZI]

Therefore, it seems that verbal doubling is not restricted only to affirmative encodings in $\Sigma$. Moreover, variation in the $C$ head could also account for the remaining differences. Clearly, such a head is not encoding any emphatic polarity feature in Rioplatense Spanish. Of course, it could be that different heads are involved in verbal doubling configurations in both languages (Focus,

\footnotetext{
${ }^{11}$ The marked status of negative verbal doubling could be attributed to the morphological status of the negative word. It seems that some speakers analyze it as a proclitic incorporated within the verbal complex head. On this analysis, verbal doubling is licensed in negative sentences.
} 
Mirativity, etc), as well. But again, we do not know at the moment the extent to which such differences are dramatic in Kayne's sense.

\section{References}

Arregi, Karlos \& María Isabel Oltra-Massuet. 2005. "Stress-by-structure in Spanish". Linguistic Inquiry 36(1): 43-84. https://doi.org/10.1162/0024389052993637

Barbiers, Sjef, Olaf Koeneman \& Marika Lekakou. 2010. "Syntactic doubling and the structure of wh-chains". Journal of Linguistics 46: 1-46. https://doi.org/10.1017/s0022226709990181

Bastos, Ana Cláudia. 2001. Facer, eu faço! Topicalizãço de constituintes verbais in português brasileiro. MA thesis, University of Campinas.

Biberauer, Theresa. 2009. "Predicate-doubling in Afrikaans: facts and comparisons". Talk given at the Annual meeting of the Linguistic Association of Great Britain, Edinburgh University.

Cable, Seth. 2004. "Predicate clefts and base-generation: evidence from Yiddish and Brazilian Portuguese". Ms., MIT.

Campos, Héctor. 1986. "Indefinite object drop". Linguistic Inquiry 17: 354-359.

Campos, Héctor. 1999. "Transitividad e intransitividad". In I. Bosque \& V.Demonte (dirs.) Gramática descriptiva de la lengua española. Madrid: Espasa Calpe. Vol. 2. cap. 24: 1519-1574.

Cardinaletti, Anna \& Michal Starke. 1999. "The typology of structural deficiency". In Henk van Riemsdijk (ed.) Clitics and other functional categories in European languages. Berlin: Mouton de Gruyter: 145-233.

Chomsky, Noam. 1993. "A minimalist program for linguistic theory". In K. Hale \& S. Keyser (eds.). The view from Building 20: Essays in linguistics in honor of Sylvain Bromberger. Cambridge, Mass.: MIT Press, 1-52.

Chomsky, Noam. 1995. The minimalist program. Cambridge, Mass.: MIT Press. https://doi.org/10.7551/mitpress/9780262527347.001.0001

Chomsky, Noam. 2000. "Minimalist inquiries: The framework". In R. Martin, D. Michaels \& J. Uriagereka (eds.) Step by step: Essays on minimalist syntax in honor of Howard Lasnik. Cambridge, Mass.: MIT press, 89-156.

Corver Norbert \& Jairo Nunes. 2007. The copy theory of movement. Amsterdam: John Benjamins. https://doi.org/10.1075/la.107

Embick, David. 2015. The morpheme. A theoretical introduction. Berlin: de Gruyter Mouton. https://doi.org/10.1515/9781501502569

Embick, David \& Rolf Noyer. 2001. "Movement operations after syntax". Linguistic Inquiry 32(4): 555-595. https://doi.org/10.1162/002438901753373005

Farkas, Donka \& Kim Bruce 2010. "On reacting to assertions and polar questions". Journal of Semantics 27: 81-118. https://doi.org/10.1093/jos/ffp010

Goldberg, Lotus. 2005. Verb-Stranding VP-Ellipsis: A cross-linguistic study. Doctoral Dissertation, McGill University. 
Gullì, Antonino. 2003. Phrasal reduplication in syntax. Doctoral Dissertation, The City University of New York.

Halle, Morris \& Alec Marantz. 1993. "Distributed Morphology and the pieces of inflection". In Kenneth Hale \& Samuel Keyser (eds.) The view from Building 20: Essays in linguistics in honor of Sylvain Bromberger. Cambridge, Mass.: MIT Press, 111-176.

Iatridou, Sabine. 1995. "Clitics and island effects". In Proceedings of PLC 19. Philadelphia: Penn Linguistics Club, 11-30.

Kandybowicz, Jason. 2007. "On fusion and multiple copy spell-out". In N. Corver \& J. Nunes (eds.) The copy theory of movement. Amsterdam: John Benjamins, 119-150. https://doi.org/10.1075/la.107.06kan

Kandybowicz, Jason. 2008. The grammar of repetition: Nupe grammar at the syntax-phonology interface. Amsterdam: John Benjamins. https://doi.org/10.1075/la.136

Kayne, Richard. 1994. The antisymmetry of syntax. Cambridge, Mass.: MIT Press. Kayne, Richard. 2005. Movement and silence. Oxford: Oxford University Press. https://doi.org/10.1093/acprof:oso/9780195179163.001.0001

Koopman, Hilda. 1984. The syntax of verbs. Dordrecht: Foris.

Kornfeld, Laura. 2005. Formación de palabras en la sintaxis desde la perspectiva de la morfología distribuida. Doctoral Dissertation, Universidad de Buenos Aires.

Kornfeld, Laura \& Inés Kuguel. 2013.’Un afijo re loco”. In A. Di Tullio (coord.) El español de la Argentina. Estudios gramaticales. Buenos Aires: Eudeba, 15-35.

Laka, Itziar. 1990. Negation in syntax: On the nature of functional categories and projections. Doctoral Dissertation, MIT.

Landau, Idan. 2006. "Chain resolution in Hebrew V(P)-fronting". Syntax 9: 32 66. https://doi.org/10.1111/j.1467-9612.2006.00084.x

Jokilehto, Dara. 2016. "Reduplication in Roman. A case of microvariation". Rivista di Grammatica Generativa 38: 149-160.

Martins, Ana Maria. 1994. "Enclisis, VP-deletion and the nature of Sigma". Probus 6: 173-205. https://doi.org/10.1515/prbs.1994.6.2-3.173

Martins, Ana Maria. 2007. Double realization of verbal copies in European Portuguese emphatic affirmation. In N. Corver \& J. Nunes (eds.) The copy theory of movement. Amsterdam: John Benjamins, 78-118.

Martins, Ana Maria. 2013. "Emphatic polarity in European Portuguese and beyond." Lingua 128: 95-123.

https://doi.org/10.1016/j.lingua.2012.11.002

McDaniel, Dana. 1986. Conditions on wh-chains. Doctoral Dissertation, The City University of New York.

Merchant, Jason. 2001. The syntax of silence: sluicing, islands and the theory of ellipsis. Oxford: Oxford University press.

Muñoz Pérez, Carlos. 2017. Cadenas e intefaces. Doctoral Dissertation, Universidad de Buenos Aires. 
Nunes, Jairo. 1999. "Linearization of chains and phonetic realization of chain links". In S. Epstein \& N. Hornstein (eds.) Working minimalism. Cambridge Mass.: MIT Press, 217-249.

Nunes, Jairo. 2004. Linearization of chains and sideward movement. Cambridge, Mass.: MIT Press. https://doi.org/10.1017/s0022226707004719

Ott, Dennis. 2015. Symmetric merge and local instability: Evidence from split topics. Syntax 18(2): 157-200 https://doi.org/10.1111/synt.12027

Ott, Dennis \& Andreea Nicolae. 2014. "The syntax and semantics of genusspecies splits in German." In R. Baglini, T. Grinsell, J. Keane, A. Roth Singerman, \& J.Thomas (eds.) Proceedings of CLS 46: 253-267. Chicago: Chicago Linguistic Society.

Pylkkänen, Liina. 2002. Introducing arguments. Doctoral Dissertation, MIT.

Roberts, Ian. 1997. "Restructuring, head movement, and locality". Linguistic Inquiry 28: 423-460.

Saab, Andrés. 2008. Hacia una teoría de la identidad en la elipsis. Doctoral Dissertation, Universidad de Buenos Aires.

Saab, Andrés. 2011. On verbal duplication in River Plate Spanish: Anti-adjacency and head copy deletion. In B. Janine, H.Jacobs \& T. Scheer (eds.) Romance language and linguistic theory 2009. Amsterdam: John Benjamins, 305-322 https://doi.org/10.1075/rllt.3

Vicente, Luis. 2007. The syntax of heads and phrases: A study of verb (phrase) fronting. Doctoral Dissertation, Leiden University.

Vicente, Luis. 2009. An alternative to remnant movement for partial predicate fronting. Syntax 12: 158-191. https://doi.org/10.1111/j.1467-9612.2009.00126.x

Wiland, Bartosz. 2008. Circumstantial evidence for syntactic head movement. Proceedings of WCCFL 27: 440-448.

Zubizarreta, María Luisa. 1998. Prosody, focus, and word order. Cambridge, Mass.: MIT Press. 